\title{
Political Conflict and State Failure
}

\section{Citation}

Bates, Robert H. 2007. Political Conflict and State Failure. In Vol. 1 of The Political Economy of Economic Growth in Africa, 1960-2000, ed. Benno J. Ndulu, Stephen A. O'Connell, Robert H. Bates, Paul Collier, and Chukwuma C. Soludo, 249-296. Cambridge: Cambridge University Press.

\section{Published Version}

http://www.cambridge.org/9780521878487

\section{Permanent link}

http://nrs.harvard.edu/urn-3:HUL.InstRepos:12211570

\section{Terms of Use}

This article was downloaded from Harvard University's DASH repository, and is made available under the terms and conditions applicable to Other Posted Material, as set forth at http:// nrs.harvard.edu/urn-3:HUL.InstRepos:dash.current.terms-of-use\#LAA

\section{Share Your Story}

The Harvard community has made this article openly available.

Please share how this access benefits you. Submit a story.

\section{Accessibility}




\title{
$7 \mid$ Political conflict and state failure
}

\author{
Robert H. Bates
}

1 Introduction

page 249

2 Patterns of state breakdown

3 The costs of civil war 253

3.1 Immediate costs 253

$\begin{array}{ll}3.2 \text { Lagged effects } & 257\end{array}$

4 State failure 261

5 Framing the problem 262

5.1 Theory of the state 262

5.2 The logic of political order 263

5.3 The model 263

5.4 Political order as an equilibrium 265

5.5 Qualitative support 268

6 Testing the argument 272

6.1 Variables 272

6.2 Core model 273

6.3 Discussion 279

7 In search of causal paths 279

7.1 Petroleum production 280

$\begin{array}{lll}7.2 & \text { Revenues } & 282\end{array}$

7.3 Political reform 286

8 Conclusion 290

References 290

\section{Introduction}

In his chapter on Ethiopia in volume 2, Alemayehu Geda contends that in addition to the "vagaries of nature," growth performance in Ethiopia

The chapter was written with financial support from the National Science Foundation (Grant SES 9905568), the Carnegie Corporation, and the Center for International Development and the Weatherhead Center for International Affairs of Harvard University. I wrote it while a Moore Distinguished Scholar at the California Institute of Technology. The chapter has benefited greatly from comments and criticisms received at seminars held at Harvard University, Guelo Brittany, and at the annual meetings of the AERC 2004 in Nairobi. Special thanks go to Steven Block for his criticisms and corrections. As ever, Karen 
"is largely determined by [the] strength and efficiency of institutions, [the] efficacy of public policies, and risk related to war" (Alemayehu 2007: 2). Of these factors, Alemayehu emphasizes the last, placing special emphasis on internal war. Internal conflict also emerges as a major determinant of economic performance in the chapters in volume 2 on Chad (Azam and Djimtoingar 2007), Sudan (Ali and Elbadawi 2007), Sierra Leone (Davies 2007), Burundi (Nkurunziza and Ngaruko 2007), Mozambique (de Sousa and Sulemane 2007), Kenya (Mwega and Ndung'u 2007), and Uganda (Kasekende and Atingi-Ego 2007), or in nearly one-third of the country studies.

In Chad and Sudan, provinces in the North have sought to dominate those in the South, and in both countries' natural resources - specifically oil represent a major prize. In Sierra Leone, diamonds rather than petroleum constitute the spoils of war, and rival political machines - each as adept at campaigning in the field of battle as in the electoral arena - seek to capture power and thus control over diamond revenues. In Burundi, a fraction of the ruling elite used their position in the military to slaughter their opponents, capture the state, and employ public power to secure private privilege. In Kenya, incumbents mobilized private militias to clear key districts of opposition voters as they reacted to the threat posed by the re-introduction of electoral competition. The stories that underlie the cases thus differ; but in each, political conflict imposed major costs upon the economy.

These cases illustrate the patterns of politics that characterize the state failure syndrome: societies militarize, governments turn predatory, and life and property become insecure. This chapter offers a theory of state failure, captures its incidence, and explores its costs in post-independence Africa.

\section{Patterns of state breakdown}

To portray and analyze patterns of state failure in Africa, this chapter makes use of two samples of African countries. The first, which I shall call the forty-six-nation sample, covers the period 1970-95 (see table 7.1) and was assembled by the Africa project at Harvard University. ${ }^{1}$ The second, the which I shall call the twenty-six-country sample, comprises the country cases of the AERC Growth Project and covers the period 1960-2000 (table 7.2).

Those who analyze state failure and civil war tend to make use of one of three datasets: those compiled by James Fearon of Stanford University,

Ferree and Smita Singh deserve much of the credit for this work. I also wish to thank Matthew Hindeman and Marcus Alexander for their technical assistance. The author alone is to be blamed for its shortcomings.

${ }^{1}$ www.people.iq.harvard.edu/ rbates 
Table 7.1 Countries in the forty-six-nation sample, 1970-1995.

\begin{tabular}{lll}
\hline 1. Angola & 17. Gabon & 33. Nigeria \\
2. Benin & 18. The Gambia & 34. Rwanda \\
3. Botswana & 19. Ghana & 35. São Tomé \& Principe \\
4. Burkina Faso & 20. Guinea & 36. Senegal \\
5. Burundi & 21. Guinea-Bissau & 37. Seychelles \\
6. Cameroon & 22. Kenya & 38. Sierra Leone \\
7. Cape Verde & 23. Lesotho & 39. Somalia \\
8. CAR & 24. Liberia & 40. Sudan \\
9. Chad & 25. Madagascar & 41. Swaziland \\
10. Comoros & 26. Malawi & 42. Tanzania \\
11. Congo, Republic & 27. Mali & 43. Togo \\
12. Côte d'Ivoire & 28. Mauritania & 44. Uganda \\
13. Djibouti & 29. Mauritius & 45. Zambia \\
14. DRC & 30. Mozambique & 46. Zimbabwe \\
15. Equatorial Guinea & 31. Namibia & \\
16. Ethiopia & 32. Niger &
\end{tabular}

Table 7.2 Countries in the twenty-six-nation sample, 1970-1995.

\begin{tabular}{lll} 
1. Benin & 10. Guinea & 19. Senegal \\
2. Botswana & 11. Kenya & 20. Sierra Leone \\
3. Burkina Faso & 12. Malawi & 21. South Africa \\
4. Burundi & 13. Mali & 22. Sudan \\
5. Cameroon & 14. Mauritius & 23. Tanzania \\
6. Chad & 15. Mozambique & 24. Togo \\
7. Congo, Republic & 16. Namibia & 25. Uganda \\
8. Ethiopia & 17. Niger & 26. Zambia \\
9. Ghana & 18. Nigeria & \\
\hline
\end{tabular}

the World Bank, or the researchers at the Peace Research Institute, Oslo (PRIO). ${ }^{2}$ Focusing on the first, Fearon classifies 15.1 percent of its 1,196 observations as experiencing civil war, the World Bank 17.7 percent, and PRIO only 10.8 percent. ${ }^{3}$ Inspection reveals that PRIO excludes from its list conflicts in Angola and Chad; the violence that engulfed Burundi beginning in 1972 and Rwanda in 1990-5; and the collapse of Sierra Leone (1972-96). These omissions make it difficult to justify the use of PRIO's data in this study.

\footnotetext{
${ }^{2}$ Fearon (2003), Sambanis (2001), Gleditsch et al. (2002).

${ }^{3}$ I here refer to Prio1000, a variable that takes the value 1 when the conflict results in an average of at least 1,000 battle deaths per year.
} 
Table 7.3 Observations positive for civil wars, forty-six African countries, 1970-1995.

\begin{tabular}{lcrrr} 
& & \multicolumn{2}{c}{ World Bank data } & \\
\cline { 3 - 4 } & & Yes & No & Row totals \\
\hline Fearon data & Yes & 912 & 51 & 963 \\
& No & 29 & 152 & 181 \\
Column totals & & 941 & 203 & 1144 \\
\hline
\end{tabular}

Note: Pearson chi2 $(1)=646.24, p=0.000$.

Fearon includes in his list civil wars in Mozambique, Senegal, Uganda, and Zimbabwe that the World Bank omits; in my judgment, Fearon misclassifies years of resistance to colonial rule (as in the case of Mozambique) and of sheer repression (as in the case of Zimbabwe) as periods of civil war. The World Bank includes conflicts in Burundi (1973, 1991-3), Zaire (1992-5) and Kenya (1991-3) that Fearon excludes; and in these instances, I would concur with the judgment of the Bank. Fearon's data set includes countries with minuscule populations (e.g. Comoros, Equatorial Guinea) which the Bank's does not. I will therefore employ the World Bank's list in this chapter, while stressing the degree to which the two sources concur in their classification of the country-year observations (see table 7.3).

Figure 7.1 depicts the incidence of civil war, by year and country. As exemplified by Angola, Chad, and Ethiopia, some countries experienced perpetual violence over the sample period. As exemplified by Burundi, Nigeria, Sudan, and others, if a country experienced a war early on, it was likely to experience one later on as well. Note, too, that civil wars in Africa became more common with time. Later sections of this chapter will seek to account for these patterns in the data.

The modal number of years for which the countries remained at war was 0: over the period 1970-95 most African countries remained at peace. The median (0) lay below the mean (7.19 years), reflecting the impact of the persistently violent states. With the variance (10.7) half again as large as the mean, there was a broad distribution of durations of violence - one that, save for states that remained at peace, is nearly flat (see figure 7.3)

Figure 7.4 is based on the twenty-six-nation sample and depicts the distribution of wars across the landlocked and coastal states and those abundantly endowed with natural resources (I use the time-varying classification developed in chapter 2). Civil wars were present in fewer than 2 percent of the observations gathered from the coastal states; by contrast, they appear in over 20 percent of those gathered from resource-rich nations and in nearly 40 percent of the observations taken from landlocked countries. 


\section{The costs of civil war}

The costs of war are both immediate and longer term. The immediate costs are the destruction of life and property and the loss of income. The longerterm costs result from the loss of capital and the reluctance, because of insecurity, to invest.

\subsection{Immediate costs}

The most obvious way in which conflict impacts upon economic growth is through the destruction of output and the means of producing it. Viewers of the news will recall with horror the devastation visited upon Freetown, Monrovia, and Mogadishu. Most Africans live in the rural areas rather than in cities, however; the largest single sector in most of Africa's economies remains agriculture. But when fighting takes place in the countryside, the destruction of life and property can be fully as devastating as that in town. A World Bank study of Mozambique found that in the war zones the agricultural sector lost 40 percent of its immobile capital, such as buildings, and 80 percent of its mobile capital, such as cattle (Collier et al. 2003). A similar study in Uganda found that in regions of active fighting, two-thirds of the households lost not only their homes and livestock but virtually all of their possessions (Collier et al. 2003: 16).

Economic decline occurs not only because of the destruction of goods and property. It also occurs because conflict raises the costs of engaging in economic activity. Alex de Waal's study (1991) of the wars between the Mengistu regime and the TPLF in Ethiopia provides a vivid illustration. The fighting destroyed crops and livestock; additional goods were lost as the army forcibly appropriated farm products in order to feed its soldiers. More significant than the loss of property, Waal reports, was the inability to employ the market. Food deficits had long characterized important regions in Ethiopia, such as those along the coast; and within the grain-producing areas there were seasonal shortfalls, particularly just prior to the time of harvest. In peaceful times, merchants from the coast would therefore import manufactured goods into the food-producing areas and sell them in the towns; using the proceeds to purchase grain, they would then return to the coastal lowlands. And within the grain-producing zones, those whose crops had yet to ripen would enter the labor market, earn wages by harvesting the crops of others, and use their earnings to purchase food for their families. During the war, however, the government leveled the towns in Tigray; it destroyed the capacity of buyers and sellers to meet and transact. By impressing private transport, seizing shipments of goods, and restricting the movement 


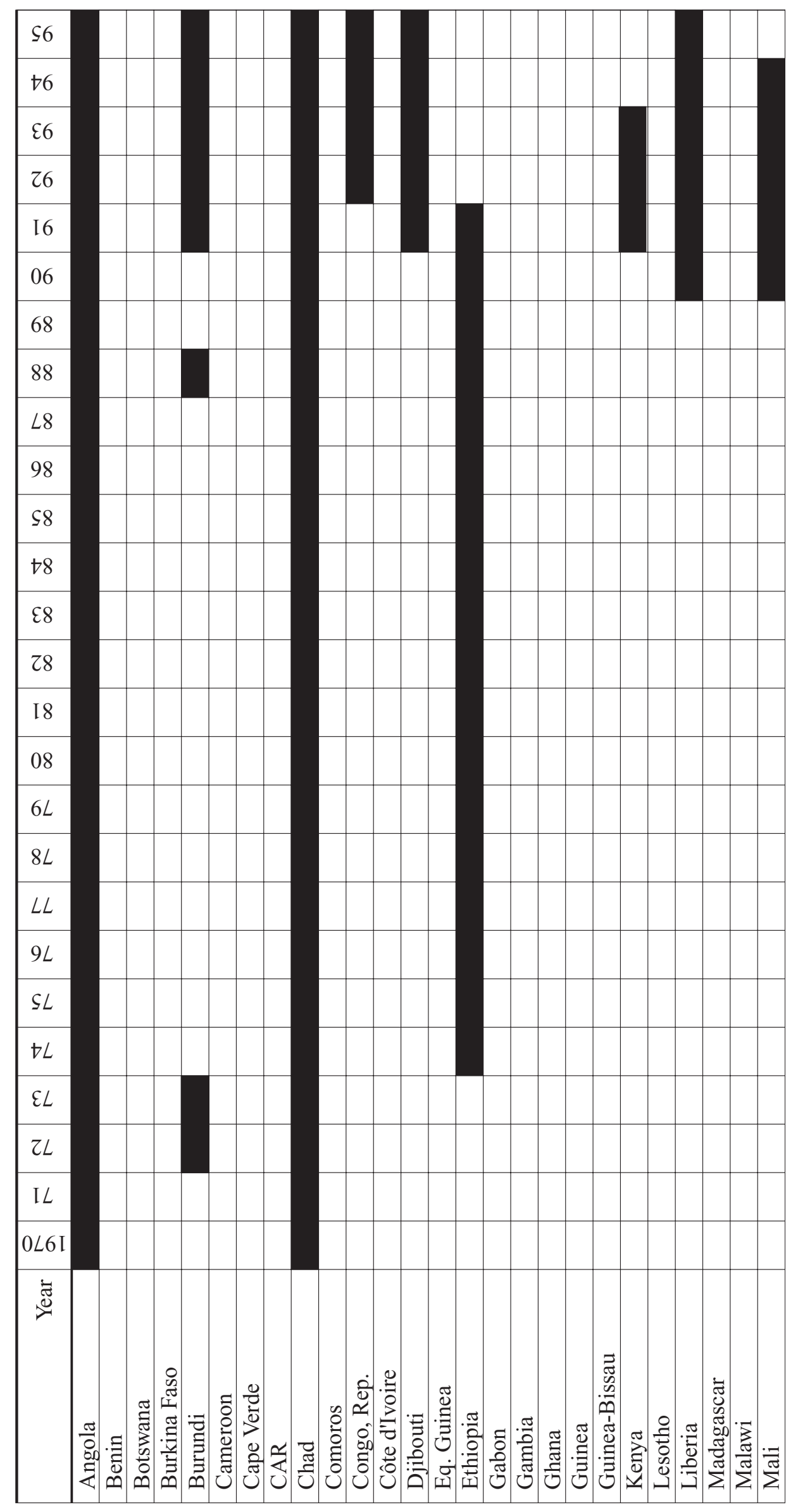




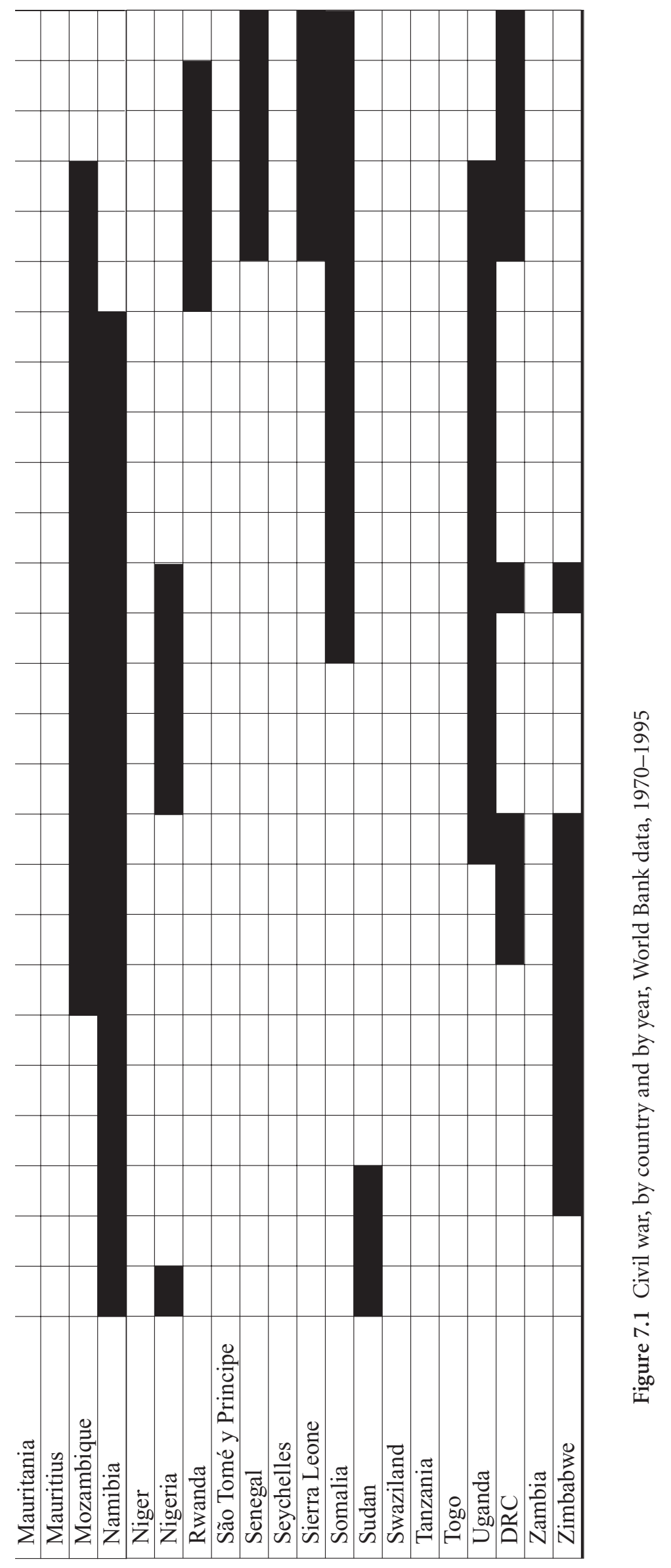




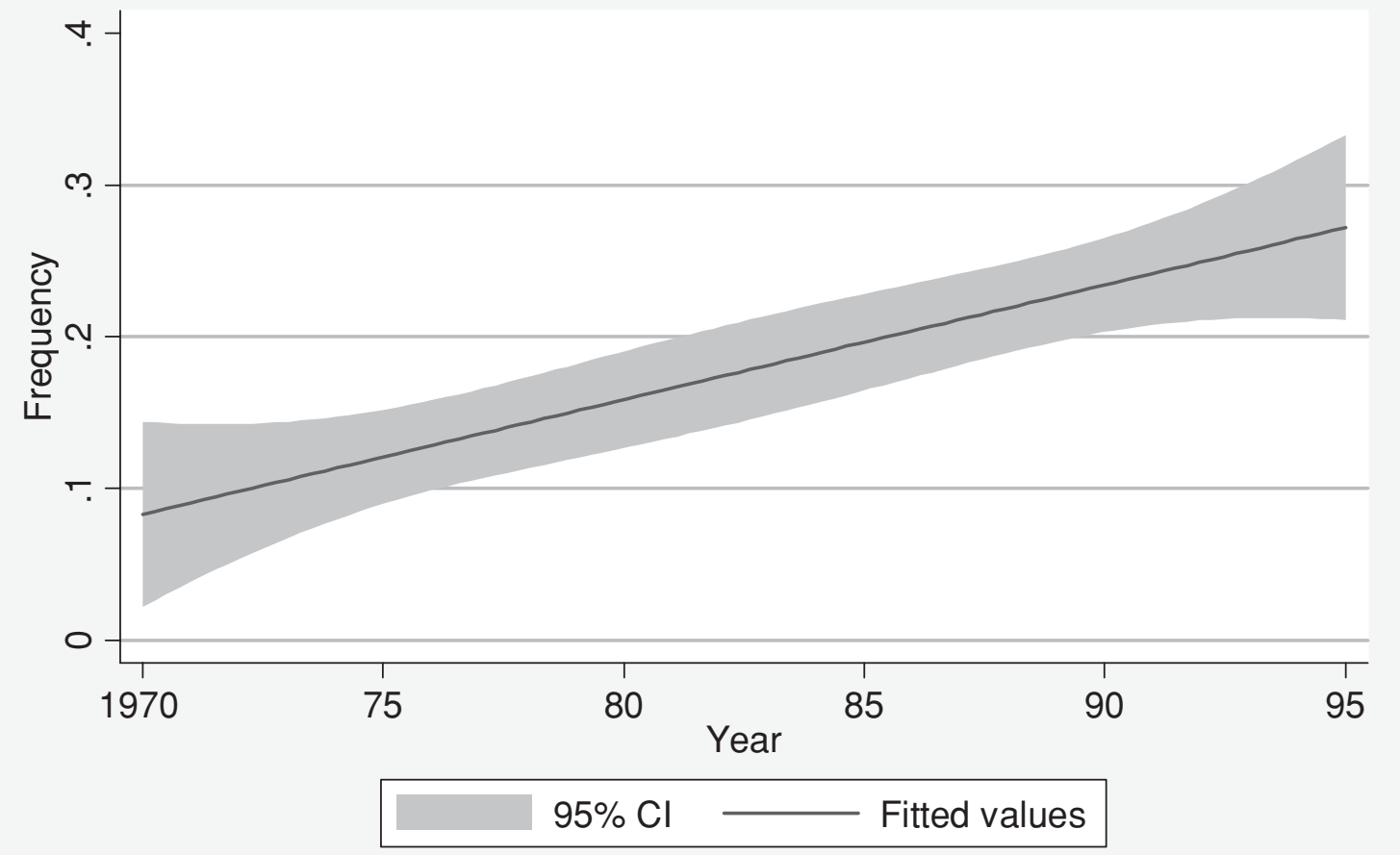

Figure 7.2 Civil wars, by year, World Bank Classification, 1970-1995

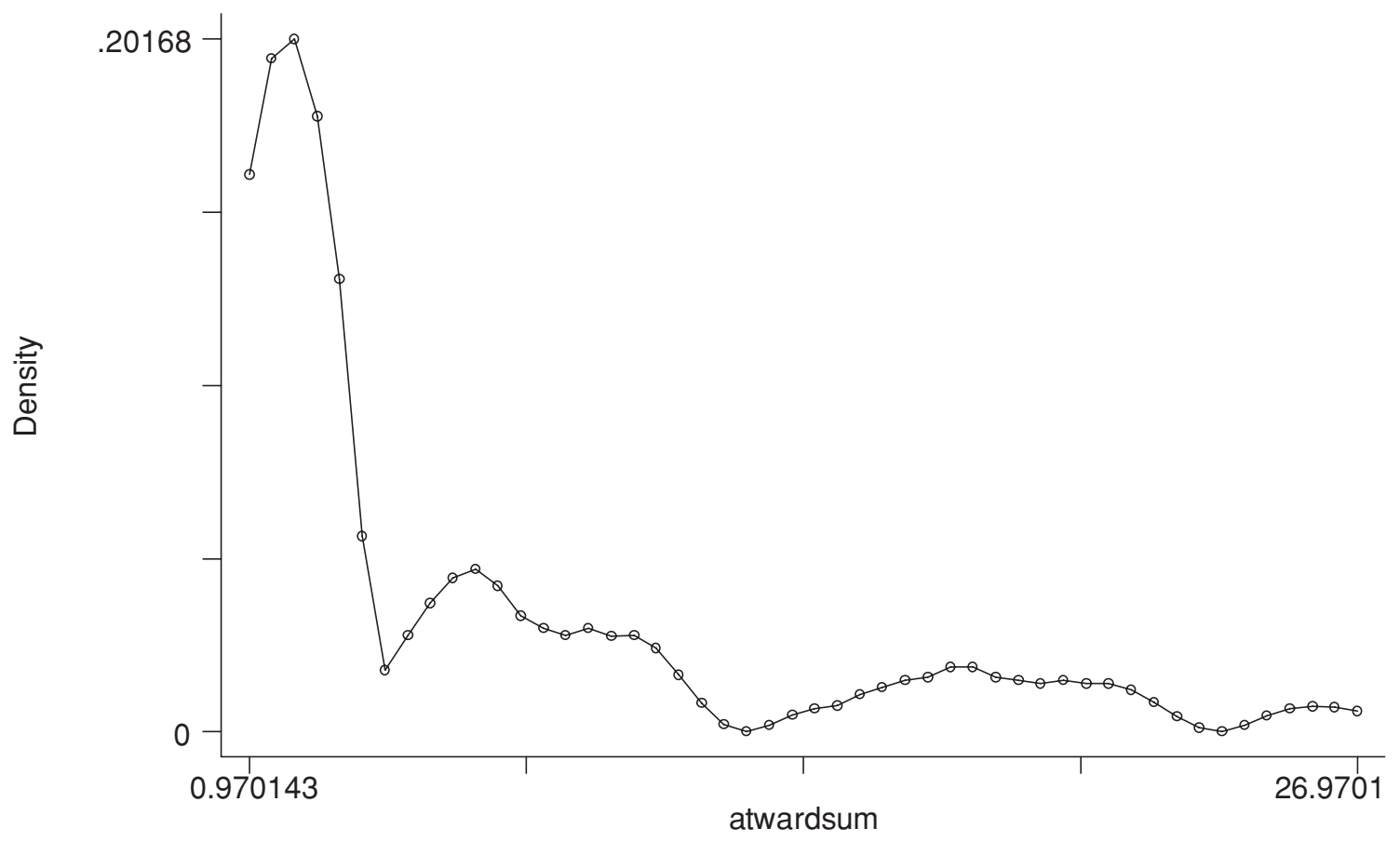

Figure 7.3 Total number of years of civil war 


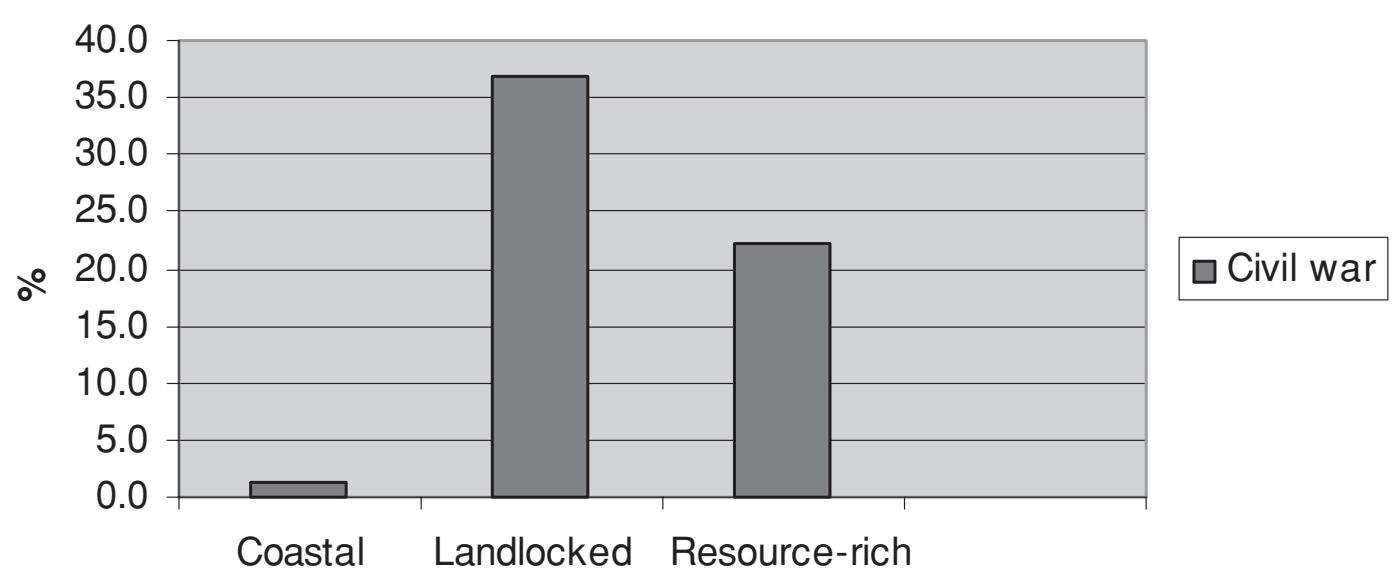

Figure 7.4 Civil war, by opportunity group

of merchants and laborers, it also forestalled the movement of grain to food deficit areas.

The result, as stated by de Waal, was that

there was almost no local trade ... In Meqele, the price of grain in December 1982 was 181 Birr per quintal . . In Shire it was 60 Birr and in North Wollo 40-90 Birr. If . . trade had been possible, the surpluses ... would have been taken to Meqele, at a transport cost of about 47 Birr and 23 Birr per quintal respectively. (de Waal 1991: 152)

Those with surpluses experienced a loss of income; those with deficits starved. Had markets functioned and exchange been possible, the one would have been better off; the latter would have survived.

As families sought the means to purchase food, de Waal notes, they sold off livestock; but with many families responding in this manner, the price of cattle plummeted. Failing to gain incomes from livestock sales, rural families then turned to off-farm employment. But with the price of necessities, such as food, rising, people stopped spending on other things. Because of the impact of the war on the urban centers of Tigray, the demand for labor declined just when the supply was increasing. Wages therefore plummeted and, with them, the capacity to purchase food. War led to famine in Tigray, de Waal writes. And the famine that resulted came not so much from physical shortages but rater from the collapse of incomes. ${ }^{4}$

\subsection{Lagged effects}

Civic conflict thus destroys physical assets and sparks sharp recessions. Adding to its impact on growth is its impact on capital formation. The

\footnotetext{
${ }^{4}$ Note the obvious parallels with Sen's analysis of the impact of famine (Sen 1984).
} 
Table 7.4 Ratio of value of debt to value of annual exports. (Study sample of African countries)

\begin{tabular}{lccccc}
\hline $\begin{array}{l}\text { State } \\
\text { breakdown? }\end{array}$ & Mean & Std dev. & $\begin{array}{c}\text { Number of } \\
\text { observations }\end{array}$ & $F$ & $P>F$ \\
\hline No & 311.37 & 517.13 & 824 & & \\
Yes & 615.79 & 660.73 & 59 & 15.50 & 0.0001 \\
Total & 331.70 & 578.16 & 883 & & \\
\hline
\end{tabular}

Source: World Bank, World Development Indicators data.

evidence suggests that civil war lowers the rate of capital formation in both the public and private sector.

It may appear incongruous to talk of government policy in the midst of political collapse. But even in periods of maximal disorder, governments continue to command public bureaucracies; they enlist them in their campaigns for military victory. In such crises, governments are impatient, however; and this impatience shapes the nature of their policies. Being insecure, governments discount long-term economic costs in favor of short-term benefits. In poor countries, ${ }^{5}$ the World Bank reports, military spending rises from an average of 2.8 percent of GDP to an average of 5 percent (Collier et al. 2003), while spending on education, infrastructure, or health care declines. In the words of the World Bank, expenditures on the military "crowd out" public investments.

Consider the findings reported in chapter 10 on political reform: in both the African and the global samples, the governments of countries listed in the problem sets of the State Failure Task Force tended to be more likely to be rated as opportunistic by investors. In the judgment of private businessmen, these governments were significantly more likely to repudiate contracts or to seize property. These actions, too, represent evidence of a strong preference for short-term gains, even at the cost of future losses from a tarnished reputation.

Turning to the twenty-six country cases studied in the AERC Growth Project, the evidence suggests that insecure governments are more likely to incur debt. As noted in table 7.4 in the years in which states were judged to have collapsed, the ratio of debt to exports doubled. And as noted in table 7.5, there was a 25 percent increase in level of government consumption - something that had to be financed either through the short-term loss of purchasing power (as a result of inflation) or by sacrificing growth (as a result of higher interest rates).

\footnotetext{
${ }^{5}$ I.e. countries with a per capita income of less than $\$ 3,000$.
} 
Table 7.5 Government consumption as a percent of GDP. (Study sample of African countries)

\begin{tabular}{lccccc}
\hline $\begin{array}{l}\text { State } \\
\text { breakdown? }\end{array}$ & Mean & Std dev. & $\begin{array}{c}\text { No. of } \\
\text { observations }\end{array}$ & $F$ & $P>F$ \\
\hline No & 16.28 & 7.04 & 548 & & \\
Yes & 18.46 & 9.18 & 64 & 5.13 & 0.024 \\
Total & 15.51 & 7.32 & 612 & & \\
\hline
\end{tabular}

Source: World Bank, World Development Indicators data.

Research by Collier, Hoeffler, and Pattillo (2002) offers insight into the impact of violence on private capital. Conflict affects both the composition and the quantity of capital, they stress. In the face of possible violence, people prefer to hold portfolios weighted toward more mobile forms of capital; they prefer liquid to fixed investments. And in an environment in which fighting destroys the fruits of productive effort, the productivity of capital declines; when fighting begins, people therefore adjust downward the amount of capital they wish to employ. The reduction in the demand for capital and the shift from fixed to liquid capital promote capital flight. As reported by Collier, Hoeffler, and Pattillo (2002), the data suggest that in 198040 percent of private wealth had been moved offshore (2002: 1). "That Africa has such a high proportion of its wealth abroad despite being capital-scarce is an indication of how much . . . other variables matter" (2002: 22). Among the most important of these variables, they imply, is the threat of conflict.

It was Fosu (1992) who first reported systematic evidence of the decline of growth in the presence of political instability and of the importance of the impact of political instability on capital formation. Rather than civil wars, Fosu focused on "elite instability," as measured by a weighted sum of reported, attempted, and successful coups. Using a sample of thirtyone African countries over 1969-86, he interacted this measure with the variables in an augmented growth equation. He found that in the presence of instability the coefficients linking capital to output declined. Countries with levels of political instability above the sample mean, Fosu reports, tended to grow an average of 1.14 percentage points more slowly than did their more stable counterparts.

Like Fosu, Gyimah-Brempong and Traynor (1999) estimate the impact of political instability on growth; they, too, explore both its direct effect on growth as well as its effect through its impact on capital. Rather than restricting attention to coups, however, Gyimah-Brempong and Traynor instead build a composite measure of political instability, using data from thirty-nine 
African countries over 1975-88 and weights derived from a principal components analysis of data on guerrilla warfare, political purges, riots, anti-government demonstrations, politically motivated strikes, and assassinations. ${ }^{6}$ A 1 standard deviation increase in political instability leads to a reduction of 0.15 percentage points in the mean rate of growth, the authors report; by influencing capital formation, violence subtracts an additional 0.25 percentage points with a one-year lag.

In 2005, Gyimah-Brempong, working with Marva Corley, returned to the study of civil war (Gyimah-Brempong and Corley 2005). Using data for 1960-96 from forty-three African countries, Gyimah-Brempong and Corley find a "very large [effect] relative to the average growth rates" in SSA (2005: 296 ) - something in excess of 4 percentage points. They confirm that the more intense the war - i.e. the longer it lasts and the higher the death rate the greater its impact. And they once again underscore the significance of the link between violence and the growth rate that runs through the formation of capital.

By affecting the quantity as well as the productivity of capital, political conflict thus has both a short- and long-term impact on growth. Adding to the latter is the fear that countries that have been violent may become violent once again, the impact of conflict on growth can be long lasting. By Collier and Hoeffler's calculations (Collier, Hoeffler, and Pattillo 1999), the longer-term effect - or the "overhang" as Collier, Hoeffler, and Pattillo (1999) phrase it - amounts to a reduction of 2.10 percentage points over the five years following a civil war.

At the end of the Cold War, Africa contained roughly 30 percent of the world's nations, 10 percent of the world's population, and 5 percent of the world's economic product. ${ }^{7}$ If marked by the toppling of the Berlin Wall in 1989, the end of the Cold War found 46 percent of the world's civil wars taking place in Africa; if by the fall of the Soviet Union in 1991, a full

6 These are the "standard" Banks measures of conflict (Banks 1999). Gyimah-Brempong and Traynor (1999) use Arellano and Bond's (1991) two-step procedure to control for the impact of reciprocal causation in the relationship between conflict and both income and growth.

7 We can select as our denominator the number of members of the United Nations (call that number UN) or the number of nations with a population of 1 million or more (call that number POP). We can select as our numerator the number of countries in SSA (call that number SSA); the total number of countries on the African continent (AF); or the number of countries in Africa (SSA-POP) or on the continent (AF-POP) with a population of 1 million or more. Africa's percentage of the world's nations (WT for world total; WT-POP for the total number of nations in the world with 1 million or more people) can then be calculated alternatively as: $\mathrm{SSA} / \mathrm{UN}=25$ percent; $\mathrm{AF} / \mathrm{UN}=28$ percent; $\mathrm{SSA} / \mathrm{WT}=22$ percent; $\mathrm{AF} / \mathrm{WT}=27$ percent; $(\mathrm{SSA}-\mathrm{POP}) /(\mathrm{WT}-\mathrm{POP})=23$ percent; $(\mathrm{AF}-\mathrm{POP}) /$ $(\mathrm{WT}-\mathrm{POP})=29$ percent. 
53 percent. ${ }^{8}$ In recent years, then, Africa has over-supplied political conflict. It is perhaps for this reason that political risk services rate Africa as the riskiest continent for investors (Collier, Hoeffler, and Patillo 1999).

\section{State failure}

Two major literatures address the sources of political disorder in contemporary Africa. One is political and points to the low quality of "governance" (World Bank 1991; Fukuyama 2004) and the other to the weakness of political institutions (Jackson and Rosberg 1982; Bratton and van de Walle 1997). Both, it is claimed, result in personalistic forms of rule based on clientelism, corruption, and repression. As stated by Christopher Clapham, the emergence of insurgency movements in West Africa in the 1990s "can be ascribed to the experience of post-independence government so bad as to lead . . . to resistance ... and to the consequences of ... immiseration, exploitation, and state decay" (quoted in Adibe 2001: 28). Such accounts remain unpersuasive, however. How can one recognize which institutions are weak, which states fragile, or which governments "bad" other than by the rise of political disorder? Insofar as these "causal" factors are characterized by their consequences, then they add little by way of explanation. They may highlight what has been observed, but they do little to explain it.

A second approach is economic and is best exemplified by the World Bank study, Breaking the Conflict Trap (Collier et al. 2003). As stated by its authors, "the key root cause of conflict is the failure of economic development" (Collier et al. 2003: 53). Stated more fully, the approach contends that

countries with low, stagnant, and unequally distributed per capita incomes that have remained dependent on primary commodities for exports face dangerously high risks of prolonged conflict. In the absence of economic development, neither good political institutions, nor ethnic and religious homogeneity, nor high military spending provide significant defenses against large scale violence. (Collier et al. 2003: 53)

The primary weakness of the political approach is that it borders on tautology. That of the economic approach is that it fails to point to the mechanisms that link economic conditions to political outcomes. While pointing to a set of relationships between macroeconomic aggregates and political behaviors, it fails to specify the micro-level mechanisms that generate those relationships or the incentives that animate them.

A fresh look is thus in order.

8 The figures are calculated from data gathered by the Peace Research Institute in Oslo on conflicts between insurgent groups and governments that generate 1,000 or more battle deaths per annum (Strand, Wilhelmsen, and Gleditsch 2002). 


\section{Framing the problem}

In choosing a vantage point from which to cut into this problem, the chapter takes counsel from both the "theory" of the state and the realities that prevail in contemporary Africa.

\subsection{Theory of the state}

According to Max Weber, the state is "a human community that successfully claims the monopoly of the legitimate use of physical force within a given territory" (Weber 1921: 1). Two features of this definition command attention: the importance of coercion and the state's claim to a monopoly of it.

In political science, many who study the politics of advanced industrial nations find Weber's emphasis on physical force largely irrelevant to the study of politics. Rather than emphasizing coercion, they instead concentrate on civic participation; and rather than putting the military at the center of the state, they instead focus on the civilian branches of government. In the context of contemporary Africa, however, Weber's characterization rings true.

Consider, for example, the prominence of the military in African politics. As documented in chapter 10 on political reform, the armed forces provided the head of state in over a third of the 1,196 country-year observations gathered from a sample of forty-six African countries over a twenty-sixyear period (1970-95). In recent years civilians have increasingly replaced military officers as chief executives; but one need only reflect upon the Eastern portion of contemporary Africa to appreciate the central role of the military. The presidents of Eritrea, Ethiopia, Uganda, Rwanda-members of the so-called "new generation" of African leaders - seized power by fighting for it. Consider, too, the presidents of Burundi, Mozambique, and Namibia. At the head of each country stood the leader of the movement that had prevailed in armed struggle. ${ }^{9}$

Given the ease with which Weber's characterization of the state maps on to the realities of Africa, when we focus on the state in this analysis, we shall focus on coercion. And we shall refer to those who head the state as "specialists in violence."

Weber emphasizes not only the importance of force; he also suggests that a political community becomes a state when it can successfully command

\footnotetext{
${ }^{9}$ While some might dismiss this pattern as distinctive of Africa, idiosyncratic and therefore of no general significance, a glance at the history that informed Weber's vision should provoke reappraisal. In Medieval Europe, the Angevins and Lancasters placed generations of warriors on the throne of England and the Merovingians and Capetians on the throne of France. As Tilly famously states, throughout the Medieval and Early Modern period, "war made the state and the state made war" (Tilly 1975: 42).
} 
a monopoly over its use. He thus points to an observable symptom of state failure: the inability of governments to secure a monopoly of violence. Taking guidance from the theory of the state and the realities of contemporary Africa, this chapter will therefore explore the conditions under which governments - or specialists in violence - succeed or fail to acquire a monopoly over the use of force. And it will take as evidence of state failure the militarization of civic society.

\subsection{The logic of political order}

Three questions thus form the agenda for this analysis. One is: under what conditions will citizens choose to disarm, leaving the government to protect their life and property? Closely related is a second: under what conditions will specialists in violence choose to employ force to defend their citizens rather than to prey upon them? And because neither political order nor the "Weberian state" are givens, there arises a third: when will these choices prevail as an equilibrium? Addressing these questions offers a deeper understanding of the nature of political order and of the conditions under which it fails.

In search of answers, I turn from the theory of the state to the theory of games. ${ }^{10}$ The players are two citizens and a specialist in violence. The equilibria of this game suggest the conditions under which order can prevail; by the same token, they suggest the conditions under which political disorder will arise. The remainder of the section presents the logic of the argument; by applying the model to African data, section 6 assesses its validity.

\subsection{The model}

Consider the behavior of three players: $G$, a specialist in violence, and two citizens, $i \in\{1,2\}$. Although $G$ is a specialist in violence, she is not endowed with a monopoly over it; the citizens, too, have access to arms and $G$ can achieve a monopoly of physical force only when the citizens set theirs aside.

By assumption, each citizen possesses a given amount of resources, denoted by $T_{i}$ (as in time), that she can allocate between work $\left(w_{i}\right)$, military preparedness $\left(m_{i}\right)$, and leisure $\left(l_{i}\right)$. That is,

Citizen $i \in\{1,2\}$ chooses $w_{i}, m_{i}, l_{i} \geq 0$ subject to $w_{i}+m_{i}+l_{i} \leq T_{i}$.

The resources devoted to work, $w_{i}$, are productive; they result in an output of $F\left(w_{i}\right)$ for player $i{ }^{11}$ Those devoted to military activity are unproductive. Rather than creating wealth, they merely redistribute it - or provide a defense against its redistribution.

${ }^{10}$ More accurately, Avner Greif, Smita Singh, and I (Bates, Greif, and Singh 2002).

11 The function $F$ is assumed to be twice continuously differentiable and concave. 
After allocating their resources, each citizen observes the decision of the other; they then (sequentially) decide whether or not to attempt to raid the other's possessions, with player 1 choosing first. The amount that one can gain from raiding depends not only on the quantity of the other's assets but also on the relative strength of the players. ${ }^{12}$

As is conventional, the citizens derive their utility from income and from leisure. They can increase their incomes by working or by employing their military capabilities to raid.

$G$, too, seeks to maximize her utility, which, like that of the citizens, derives from income and leisure. As a specialist in violence, however, $G$ does not need earn her income from laboring in a farm or factory; rather, she gains it through the use of force. She can increase her income by engaging in predation or by collecting fees for the provision of a valued service: the provision of security for those who seek to relax or to create wealth.

Three assumptions characterize the military balance between $G$ and private citizens. Given that private agents are themselves capable of violence, (i) when $G$ preys upon the economic output of a citizen $i, G$ succeeds in capturing her wealth only with some probability. (ii) $G$ engages in predatory activity only if the expected revenue from its use of violence exceeds its cost of military activity. (iii) And $G$ can dispossess only one agent per period.

Should $G$ engage in predation, then the revenue she seizes from $i$ equals the probability of successful predation, multiplied by player $i$ 's income from work and raiding, net the amount $i$ has paid in taxes. Should $G$ choose to

12 More generally, throughout the chapter we ignore the possibility that one agent eradicates the other. Similarly, we do not consider a situation in which one group gains military resources by raiding the other. When this is the case, one group is likely to come to dominate the other. This is the situation we do not consider here. Alternatively, one can consider our analysis as related to a situation in which property rights are determined endogenously through interactions among the economic agents. The degree to which one can secure property rights depends upon relative coercive capabilities. See, for example, Skaperdas (1992), Grossman (1995), and Muthoo (2000). The model also puts to one side evolutionary forces and specialization in the use of violence (as in Moselle and Polak 2001); asymmetries among the agents (as in, for example, Grossman and Kim 1995 and Muthoo 2000); the impact of past conflicts on one's current military capabilities (Fearon 1998); uncertainty and loss of potential exchange (discussed in Skarpedas 1996) and moral hazard issues.

By the same token, this framework enables us to extend the analysis beyond that possible in other works. Specifically, it allows us to examine the endogenous determination of prosperity and violence. See the papers cited above, as well as Usher (1989) and Skaperdas (1992). The model in Muthoo (2000) is closest to ours. While it explores the impact of asymmetries (which we do not), it does not enable agents to invest in military capabilities (as we do), explore such issues as deterring raids by consuming leisure, or examine the welfare implications of the state. 


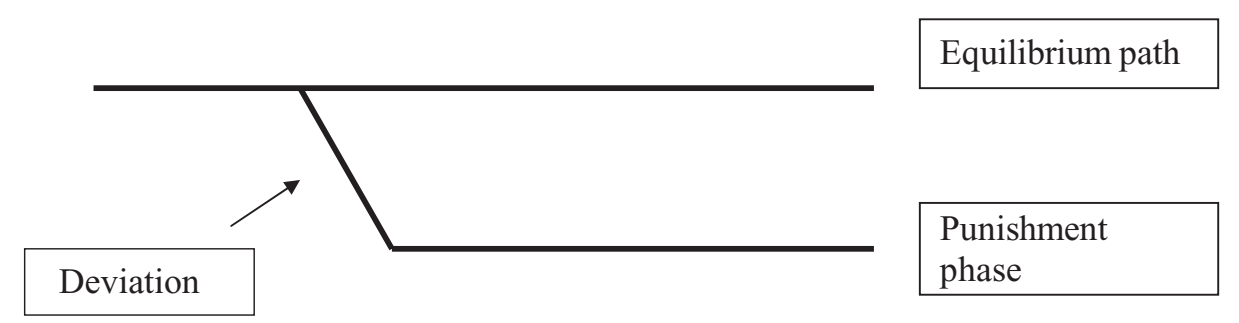

Figure 7.5 The path of play

secure her income from taxes, then her income is simply the amount of taxes paid by each private agent who has chosen to do so.

The tableau is thus peopled by a specialist in violence and two citizens, each seeking to maximize her utility and each endowed with the capacity to consume leisure or to secure income, if necessary, by the use of force. The foundations of political order are captured by the conditions for an equilibrium in which the specialist chooses to refrain from predation and to provide security instead and in which the citizens refrain from taking up arms and engage in leisure and productive activity instead.

To locate such an equilibrium, we cast the interaction between $G$ and the citizens as a repeated game; in such a setting, prospective losses help to define the equilibrium path of play (figure 7.5). The principal threats of interest in this game are the losses that arise from state failure. When states fail, specialists in violence turn to predation; they become warlords. Rather than earning her income from safeguarding the possessions of others, $G$ instead seizes them. The citizens, for their part, stop paying taxes and re-arm, either so as to raid or to defend themselves against raids by $G$ or other citizens. Because the citizens re-allocate resources from leisure and production to military endeavors, both income and security decline.

The equilibrium of this sub-game can be called the state failure equilibrium. In it, there is neither security nor prosperity. It is the possibility of a reversion to the payoffs under state failure that constitutes the threat that promotes - or fails to promote - the decision to adhere to the choices that yield political order (figure 7.5).

\subsection{Political order as an equilibrium}

To be more precise, then, the conditions for political order are:

- Each private agent chooses $w_{i}, m_{i}, l_{i}$ optimally (given the strategies of other players); refuses to raid; and pays taxes to $G$, if the other agent has not raided or if $G$ has refrained from seizing the wealth of a private agent. 


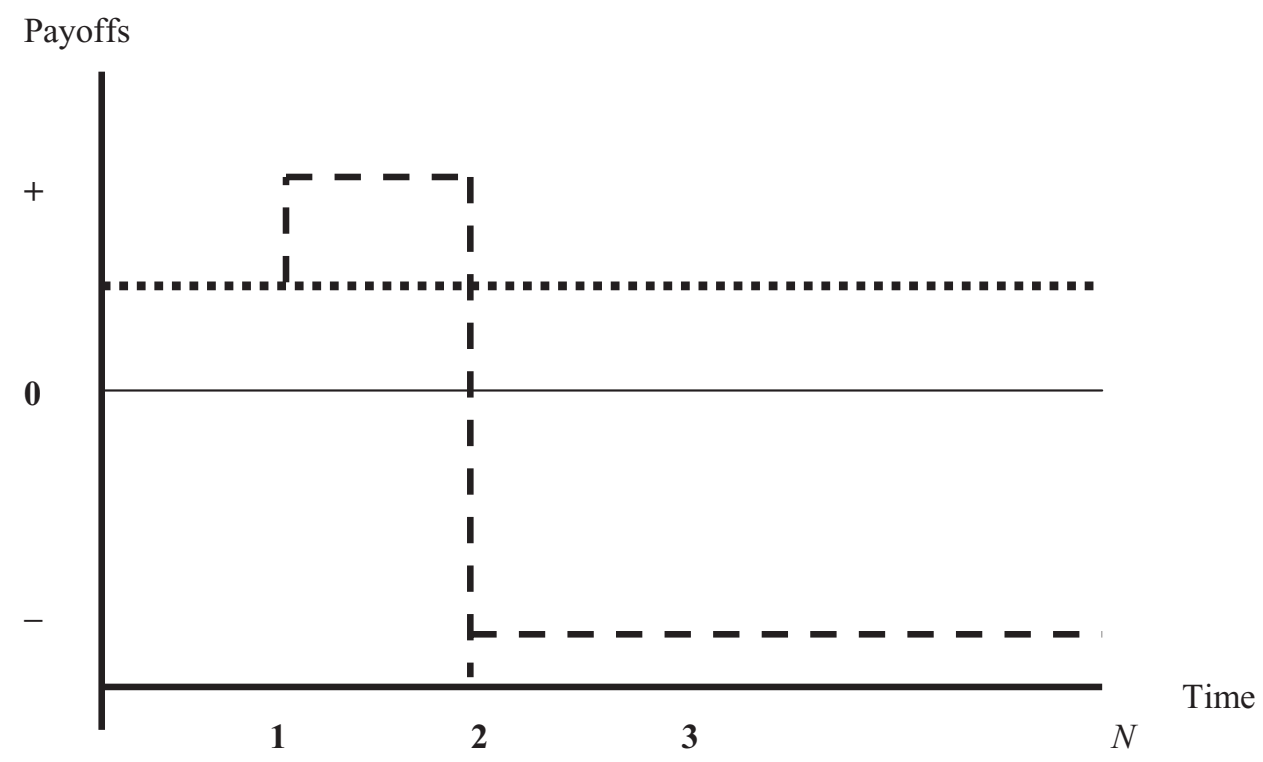

......... Payoffs on the equilibrium path

_ _ _ Payoffs from defection and subsequent punishment

Figure 7.6 Payoffs from strategy choices

Otherwise, the private agents "revolt," refuse to pay taxes, and revert to self-defense.

- $G$ refrains from predating as long as neither private agent raids or fails to pay taxes. If either agent raids or fails to pay taxes, $G$ then becomes predatory and seizes the wealth of the private agents. ${ }^{13}$

Under what conditions will these strategies be sustained as an equilibrium? For a strategy to be an equilibrium strategy, no player should be able to gain from deviating after any history, when deviation results in a reversion to the state failure equilibrium. That is:

- No private agent should be able to gain by raiding or refusing to pay taxes

- Nor should an agent be able to gain by altering the allocation of her resources between work, leisure, and military preparation

- G's threat to predate must be credible

- And $G$ must find it optimal not to predate if the economic agents adhere to their strategies.

In pondering these conditions, focus upon $G$, noting both the incentives that prevail in equilibrium and those that arise should a deviation occur

${ }^{13}$ Considering a similar equilibrium in which $G$ punishes an agent who raided or failed to pay tax without reverting to the state failure equilibrium does not change the analysis. 
(consult once again figures 7.5 and 7.6). Because the citizens and $G$ are locked in a game, their fates are interdependent. The citizens' expectations of $G$ and their response to changes in her incentives also affect their willingness to adhere to the equilibrium path of play.

$G$ 's incentives to adhere to the equilibrium choice of strategies derive from the revenues she can secure from taxation (figure 7.6). To induce $G$ to refrain from predation, the tax level, $\tau$, needs to be high enough that $G$ finds it optimal, given the private agents' strategies, to refrain from confiscating the agents' wealth if they have paid their taxes. But taxes must also be sufficiently low that private agents prefer to purchase the services of $G$ rather than to incur the costs of providing their own security. That is, the level of revenues needs to satisfy both $G$ 's and the citizens' participation constraints.

Should taxes not be fully paid, $G$ must choose between punishing and thereby triggering a reversion to the state failure equilibrium or continuing to play the strategies that define political order. Should public revenues exceed the payoffs under state failure, then $G$ would prefer to continue to receive them rather than to punish, thus triggering state failure. The tax level must therefore not be so high that $G$ 's threat to predate if taxes are not fully paid remains credible. Both the need to fulfill the citizens' participation constraint and the need to fill G's credibility constraint thus imply an upper bound on the level of public revenues.

As suggested by figure 7.6, however, conditions off the equilibrium path also shape the incentives for $G$. In particular, for $G$ to forswear the shortterm benefits of opportunism, she needs to fear the shadow cast by state failure.

The low levels of payoffs under state failure help to deter predation. Should $G$ be assured of high levels of income even in the midst of political disorder, however, she may not fear the loss of tax payments that would result were she to behave opportunistically. And should $G$ discount the future at too high a rate, then immediate prospects may outweigh future losses, weakening $G$ 's incentives to behave in a prudential manner. Should $G$ consider her future insecure, then the long-term but moderate gains to be reaped by acting with restraint would decline in value; so, too, would the long-term losses that $G$ would endure by way of punishment. The temptation to veer from the equilibrium path would thus strengthen, raising the likelihood of actions that would provoke state failure.

The discussion thus far has focused on the incentives of $G$. But note, too, the behavior of the private citizens. If public revenues decline, then, understanding $G$ 's incentives, the citizens might fear their government's behavior. They might expect the specialist in violence to begin to behave as a predator, using her power to extract resources from the private economy. So, too, if G's hold on power becomes less secure: the citizens might then fear that their government - now facing greater prospects of the loss of 
power - would now begin to despoil rather than to protect. And should a major new source of wealth arise - a resource boom, say; or discoveries of oil or mineral deposits - comprehending the incentives that shape the choices of the specialist in violence, the citizens might anticipate a change in the conduct of their government. They might anticipate that the government would forswear costly efforts on their behalf and turn instead to consuming the bounty created by the bonanza. In anticipation of the transformation of the specialist's role - her change from protector to predator - the citizenry would itself then alter its behavior: it would revert to the private provision of security and pick up arms.

The model thus suggests three testable propositions:

1. That the likelihood of state failure should be related to the level of public revenues.

2. That insofar as governments become more myopic when they face higher levels of risk, the likelihood of state failure should rise when their political fortunes become insecure.

3. And that governments in economies that contain valuable resources should experience higher levels of disorder than governments in other economies.

\subsection{Qualitative support}

Note that these propositions map closely onto key features of Africa's development experience. Because the propositions limn African realities, the logic that generates them gains credibility.

\subsubsection{Revenue}

Consider public revenues. Taxes on trade provide the bulk of public revenues in Africa. When oil prices rose in the 1970s, they triggered a recession in the global economy, resulting in a fall in the demand for Africa's exports. Government incomes atrophied as a result.

The late-century rise of the informal economy added to the damage inflicted by the decline of exports. Where governments had imposed price controls, production and exchange exited the formal economy and shifted to the "shadow" economy, where prices remained uncontrolled and incomes exempt from taxation. ${ }^{14}$ Where governments had over-valued the national currency, exports flowed through "illicit" channels; when smuggled, goods

14 See the remarkable trilogy: MacGaffey $(1987,1991)$ and MacGaffey and Bazenguissa-Ganga (2000). 
remained untaxed (see World Bank 1994; Dossou and Sinzogan, with Mensah 2007; Doumbouya and Camara 2007). And where crop prices were controlled by marketing boards, the rise in prices for goods bought off the farm posed a threat to farm incomes. In response, peasants either sold their crops in "parallel" markets, where they could command higher prices, or withdrew from the market economy (Bates 1981; Hyden 1981; de Sousa and Sulemane 2007). In both town and country, then, the response of the private sector to the policy choices of governments led to the contraction of the tax base.

\subsubsection{Uncertainty}

Until the mid-1990s, the majority of the African governments were authoritarian: on average, one-third of the heads of state came from the military and three-quarters presided over no-party or single-party systems (see chapter 10 on political reform). The late 1970s marked the peak period of military rule; the late 1980s that of single-party systems (see chapter 10). Then came the period of political reform. As the number of competitive party systems rose so, too, did the percentage of states in which incumbents were openly subject to organized political opposition. In the last decade of the sample period 1970-95, multi-party political systems became the modal form of government in Africa. Governments that had faced no challengers now had to compete for office. They became less secure.

As noted by Bratton and van de Walle (1997), in 1980-5, nine of the seventeen countries in their sample held competitive elections; in the period 1990-4, the number rose to thirty-eight. And while before the 1990s only one African head of state had been voted out of office, between 1990 and 1994 the number rose to eleven, with three others choosing not to run (Block 2002: 206).

\subsubsection{Natural resources}

Consider, too, the impact of natural resources. Cilliers (2000), Hirsch (2001), Collier and Hoeffler (2002), and others (Human Rights Watch 1999) stress the link between diamond deposits and the war in Angola. Reno (Reno 1998, 2000) emphasizes the link between natural resources and civil wars in Sierra Leone and Liberia. Johnson (2003) stresses the role of oil in the civil war in Sudan, and Zinn and others (Kirk-Greene 1971; Suberu 2001; Zinn 2005) the impact of oil on political conflict in Nigeria. So pervasive is the link between resource wealth and political conflict that it has given rise to a literature on the "resource curse" - a force disrupting politics, it is claimed, in Indonesia, Russia, and the Middle East as well (Chaudry 1997; Ross 2003). 


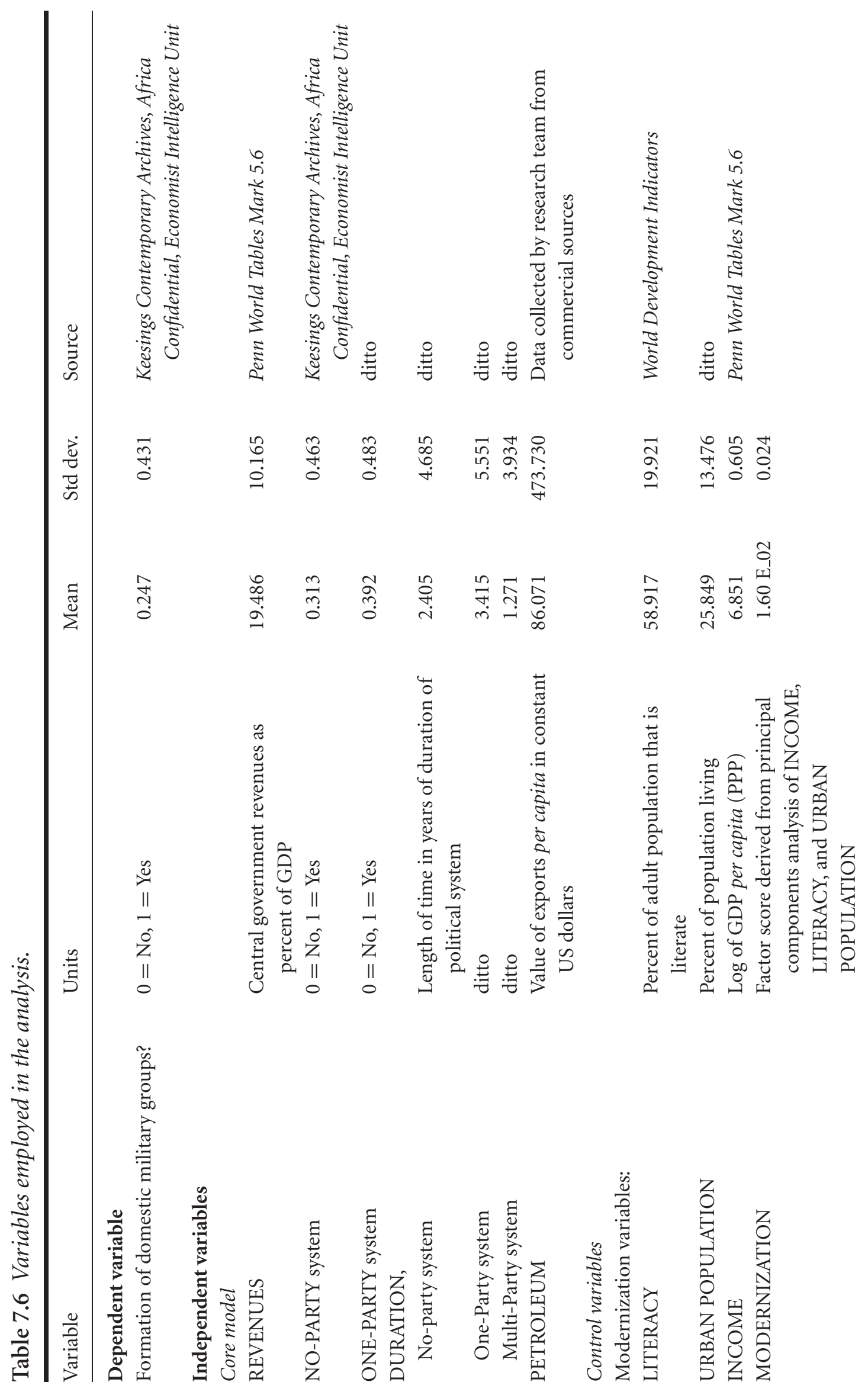




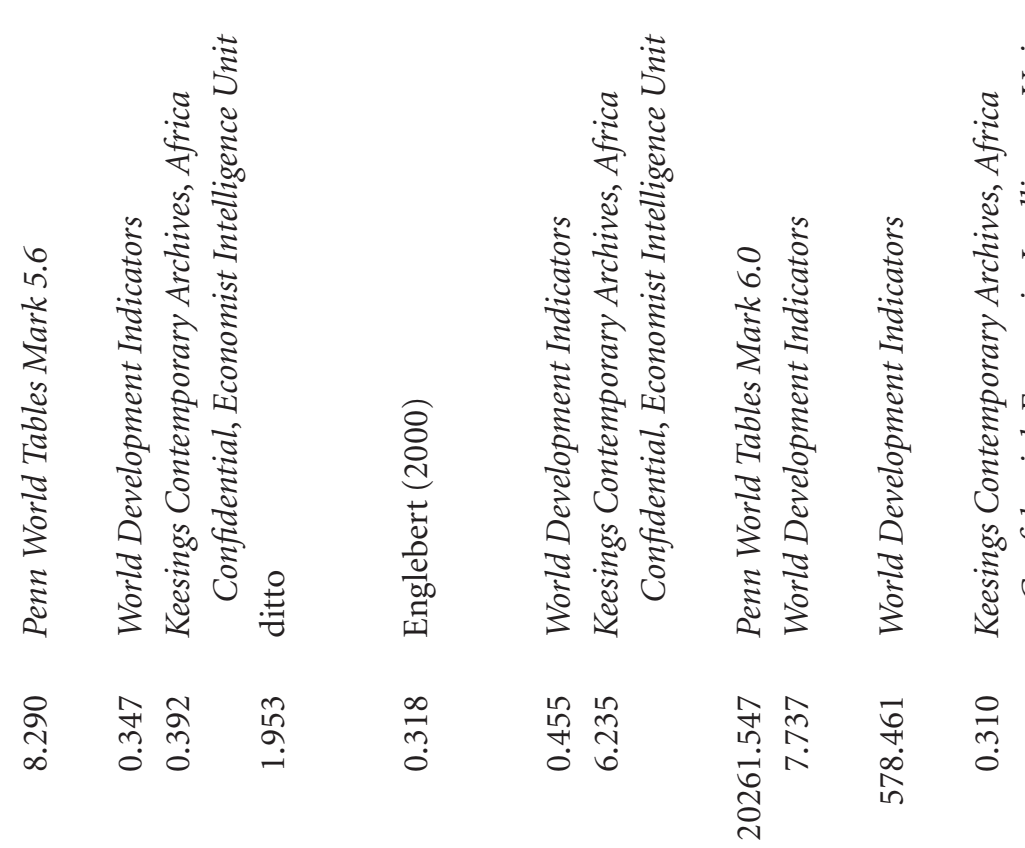

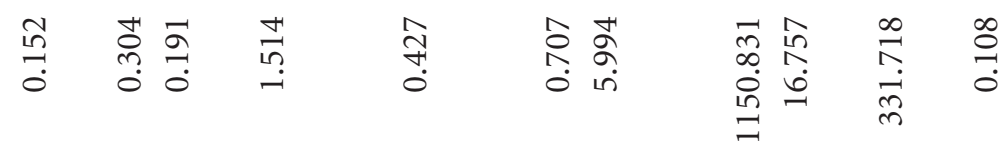

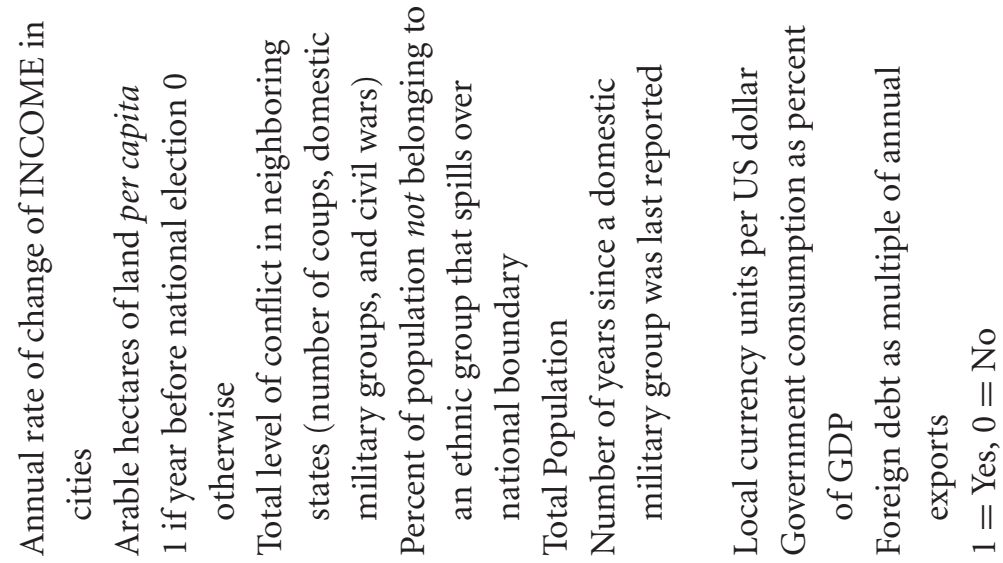

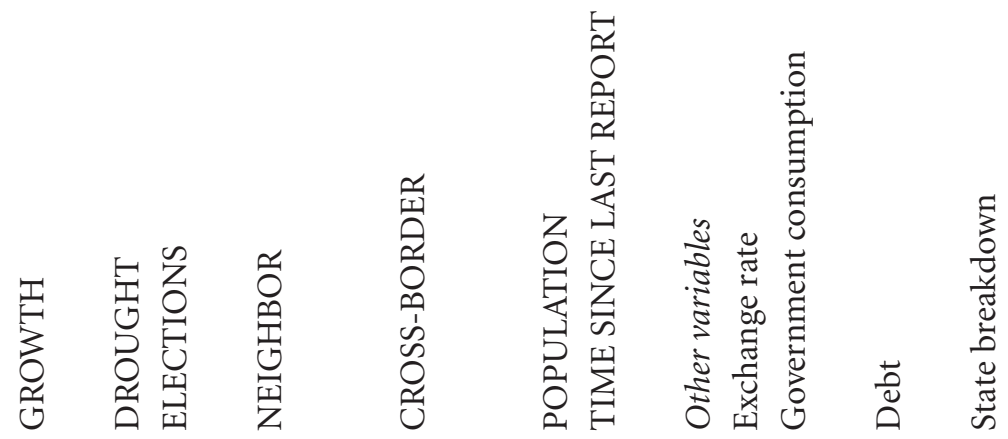


The logic that underlies our analysis of political disorder thus resonates with accounts of politics in Africa. The argument is thus plausible. It is time to assess its validity.

\section{Testing the argument}

\subsection{Variables}

According to the model, when people anticipate that incentives now favor predation by the specialists in violence, they revert to the private provision of security. That is, they arm themselves. We therefore take as our indicator of state failure the formation of private militias. ${ }^{15}$ In gathering data to test the argument, coders answered the following question: "For a given country in a given year: were there reports of a private military organization?" 16 If the answer was "yes," then the dependent variable takes the value 1; if "no," the value 0 .

Dividing the magnitude of central government's revenue for a given year by the magnitude of its GDP generated a measure of PUBLIC REVENUES. Price data and production figures collected from commercial sources yielded the value of each country's annual, per capita PETROLEUM production. Data on Africa's political systems indicated for each year whether the head of state presided over a NO-PARTY, ONE-PARTY, or MULTI-PARTY political system, thus capturing the level of political competition and suggesting the rate of discount. Table 7.6 provides a list and description of the variables and notes the sources from which they were taken.

The dependent variable is qualitative. Because it is bounded from above by 1 and from below by 0 , the errors from regression will not be identically distributed. I therefore employ the probit rather than the normal distribution; when introducing fixed effects, I employ the conditional logistic model.

Missing values in the data pose a major problem for the analysis. Not only is there a great deal of it, but also there is every reason to presume that it correlates with the likelihood of violence. ${ }^{17}$ Resorting to case-wise deletion - that is, to dropping observations that lack data for key variables would decrease the efficiency and increase the potential for bias in the estimates. It would also reduce the number of cases relative to the depth of the panel, thereby introducing an additional source of bias (Judson and Owen 1999).

${ }^{15}$ It is the militarization and not the violence that the model explains. For a thoughtful treatment of the implication of rationality for conflict, see Fearon (1995).

16 Recall the sources in $n .2$.

17 This will come as no surprise to anyone who studies Africa. See Honaker (2000). 
A second major problem arises from the impact of variables omitted from the models; should they affect both the dependent and independent variables, any relationship between the two would be spurious. Endogeneity poses yet another problem. Changes in the dependent variable (the level of insecurity) could yield changes in the independent variable (such as public revenues); the estimated relationship between the two would thus include a component of reciprocal causality.

Methods developed by Rubin and others (Rubin 1996; Schafer 1997) provide an alternative to case-wise deletion, generating imputed estimates of the missing values and their distributions. Given the magnitude and nature of the problems posed by missing data, I employed no method that could not be implemented on multiple, imputed data sets. The introduction of fixed effects provided a response to the second difficulty. I addressed the third by introducing instrumental variables.

\subsection{Core model}

Table 7.7 presents the core model. The model contains measures of the variables whose values affect the possibility of political order. The dependent variable is the likelihood that civil society will take up arms. ${ }^{18}$ Column (1) contains estimates drawn from the pooled set of data using a probit model; column (2) includes fixed effects and employs a conditional fixedeffects logit model; column (3) also applies a probit model, but one that employs instrumental variables to correct for the endogeneity of public revenues. $^{19}$

Estimates from the pooled sample suggest that states whose governments collect a large percentage of their GDP as government revenues are less likely to exhibit symptoms of state failure. When corrected for endogeneity bias (column (3)), the quadratic term is positive and significant, suggesting an upper bound to the range in which additional revenues dampen the tendency of armed groups to form. When fixed effects are included in the estimations,

18 More precisely, the likelihood that there will be a report of the formation of domestic military groups.

19 The instruments included first- and second-period lagged values of public revenues; firstand second-period values of primary product exports; lagged measures of the portion of government taxes derived from trade; and the weighted annual average growth rate of the G7 economies. The instruments are strongly correlated with the present level of public revenues; there is no reason to regard them as possessing a strong relationship with the likelihood of the formation of armed groups in the present period. Nor are past levels of public revenues likely to be correlated with the shock on the probability of the formation of private militias. Standard tests suggest that the instruments are "strong." For reasons given above, the level of public revenues enters the equation in quadratic form. The value of petroleum production enters in quadratic form as well, not for theoretical reasons but because that specification yields more precise and robust estimates. 
Table 7.7 The core model.

\begin{tabular}{|c|c|c|c|}
\hline Variable & $\begin{array}{l}\text { Pooled sample } \\
\text { (probit estimates) } \\
\text { (1) }\end{array}$ & $\begin{array}{l}\text { Conditional logits } \\
\text { (fixed effects) } \\
\text { (2) }\end{array}$ & $\begin{array}{l}\text { Instrumental variables } \\
\text { (probit estimates) } \\
\text { (3) }\end{array}$ \\
\hline REVENUES & $\begin{array}{l}-0.055 \\
(0.025)^{* *}\end{array}$ & $\begin{array}{l}-0.055 \\
(0.063)\end{array}$ & $\begin{array}{l}-0.151 \\
(0.069)^{* * *}\end{array}$ \\
\hline $\begin{array}{l}\text { REVENUES } \\
\text { SQUARED }\end{array}$ & $\begin{array}{l}0.001 \\
(0.00)\end{array}$ & $\begin{array}{l}0.001 \\
(0.001)\end{array}$ & $\begin{array}{l}0.002 \\
(0.00)^{* * *}\end{array}$ \\
\hline NO-PARTY & $\begin{array}{l}-0.407 \\
(0.214)^{*}\end{array}$ & $\begin{array}{l}-1.110 \\
(0.430)^{* * *}\end{array}$ & $\begin{array}{l}-0.539 \\
(0.12)^{* * *}\end{array}$ \\
\hline ONE-PARTY & $\begin{array}{l}-0.691 \\
(0.258)^{* * *}\end{array}$ & $\begin{array}{l}-2.240 \\
(0.470)^{* * *}\end{array}$ & $\begin{array}{l}-0.610 \\
(0.09)^{* * *}\end{array}$ \\
\hline DURATION & & & \\
\hline ... No-Party & $\begin{array}{l}0.07 \\
(0.021)^{* * *}\end{array}$ & $\begin{array}{l}0.024 \\
(0.037)\end{array}$ & $\begin{array}{l}0.074 \\
(0.00)^{* * *}\end{array}$ \\
\hline ... One-Party & $\begin{array}{l}0.045 \\
(0.016)^{* * *}\end{array}$ & $\begin{array}{l}0.171 \\
(0.037)^{* * *}\end{array}$ & $\begin{array}{l}0.038 \\
(0.00)^{* * *}\end{array}$ \\
\hline ... Multi-Party & $\begin{array}{l}0.001 \\
(0.025)\end{array}$ & $\begin{array}{l}0.077 \\
(0.065)\end{array}$ & $\begin{array}{l}0.006 \\
(0.00)^{* * *}\end{array}$ \\
\hline PETROLEUM & $\begin{array}{l}0.190 \\
(0.269)\end{array}$ & $\begin{array}{l}0.293 \\
(0.441)\end{array}$ & $\begin{array}{l}0.295 \\
(0.02)^{* * *}\end{array}$ \\
\hline $\begin{array}{c}\text { PETROLEUM } \\
\text { SQUARED }\end{array}$ & $\begin{array}{l}-0.031 \\
(0.037)\end{array}$ & $\begin{array}{l}-0.047 \\
(0.059)\end{array}$ & $\begin{array}{l}-0.041 \\
(0.00)^{* * *}\end{array}$ \\
\hline $\begin{array}{l}\text { TIME SINCE } \\
\text { LAST REPORT }\end{array}$ & $\begin{array}{l}-0.087 \\
(0.017)^{* * *}\end{array}$ & $\begin{array}{l}-0.019 \\
(0.024)\end{array}$ & $\begin{array}{l}-0.082 \\
(0.00)^{* * *}\end{array}$ \\
\hline Constant & $\begin{array}{l}0.429 \\
(0.340)\end{array}$ & $\begin{array}{l}- \\
-\end{array}$ & $\begin{array}{l}1.529 \\
(6.550)\end{array}$ \\
\hline No. observations & 1084 & 847 & 1084 \\
\hline
\end{tabular}

Robust standard errors in parentheses; Significance levels: ${ }^{* * *} 0.01 ;{ }^{* *} 0.05 ;{ }^{*} 0.1$.

the coefficients become insignificant, however. One reason may be that the variables are "slow-moving" and thus may not generate much variation in differenced form.

Each of the three statistical models indicates that states governed by noparty and one-party systems are significantly less likely to yield reports of the formation of armed groups. In this instance, it is the fixed effects estimates that yield the most relevant insights. Because of differencing, the coefficients can be interpreted as indicating the impact on political order of 
a change from a no- or single-party to a multi-party system. Note that the coefficients of the party system variables are larger than those derived from the pooled sample. The results suggest that a change to competitive politics is significantly associated with an increase in the likelihood of political disorder. $^{20}$

Basing estimates upon the coefficients of the instrumental variable model (results not shown here) indicates that the largest (marginal) effects arise from petroleum production and the party system. When, on average, the per capita value of petroleum production reaches $\$ 100$, then the likelihood of the formation of private militias rises by nearly 3 percentage points. A change from a no-party to a competitive party system increases the likelihood by 5 percentage points; a change from a one-party to a competitive party system increases it by 6 .

Table 7.8 adds a collection of control variables to the model. These include measures of modernization: INCOME, LITERACY, and URBAN POPULATION, plus a composite MODERNIZATION score (see table 7.6 for details). The controls also include measures of shocks. Two are economic: short-term changes in GROWTH and DROUGHT. ${ }^{21}$ A third is political and records the incidence of a national ELECTION. Others (e.g. Sambanis 2001; Fearon and Laitin 2003; see also Herbst 2000) stress the importance of state size, noting that large states are more costly to police. To control for size, I include a measure of POPULATION.

Political disorder in one country affects the likelihood of disorder in its neighbors (Murdoch and Sandler 2002); and the presence of military groups in one year can increase the likelihood of their presence in the next. The variable NEIGHBOR provides a measure of the number of domestic military groups, civil wars, and international conflicts in neighboring countries and another, CROSS-BORDER, records the percentage of the state's population that belong to groups whose membership spills across national boundaries. As data for the last have been gathered for only one period (see Morrison et al. 1989; Englebert 2000; Englebert, Tarango, and Carter 2002), the measure is time-invariant; it is therefore interacted with NEIGHBOR when entered in the fixed-effect equations. A measure of the TIME SINCE LAST REPORT helps to correct for the interdependence between the annual observations.

20 The introduction of period effects does not alter this finding.

21 Unlike Miguel, Shanker, and Sergenti (2004), I include both DROUGHT and GROWTH in all equations. During periods of drought, pastoralists seeking grazing land alter their migration routes and therefore pose a threat to the land rights of others. Because drought thus affects the likelihood of disorder through its impact on land rights as well as on growth, it is not a valid instrument for growth. I therefore include it among the control variables. 


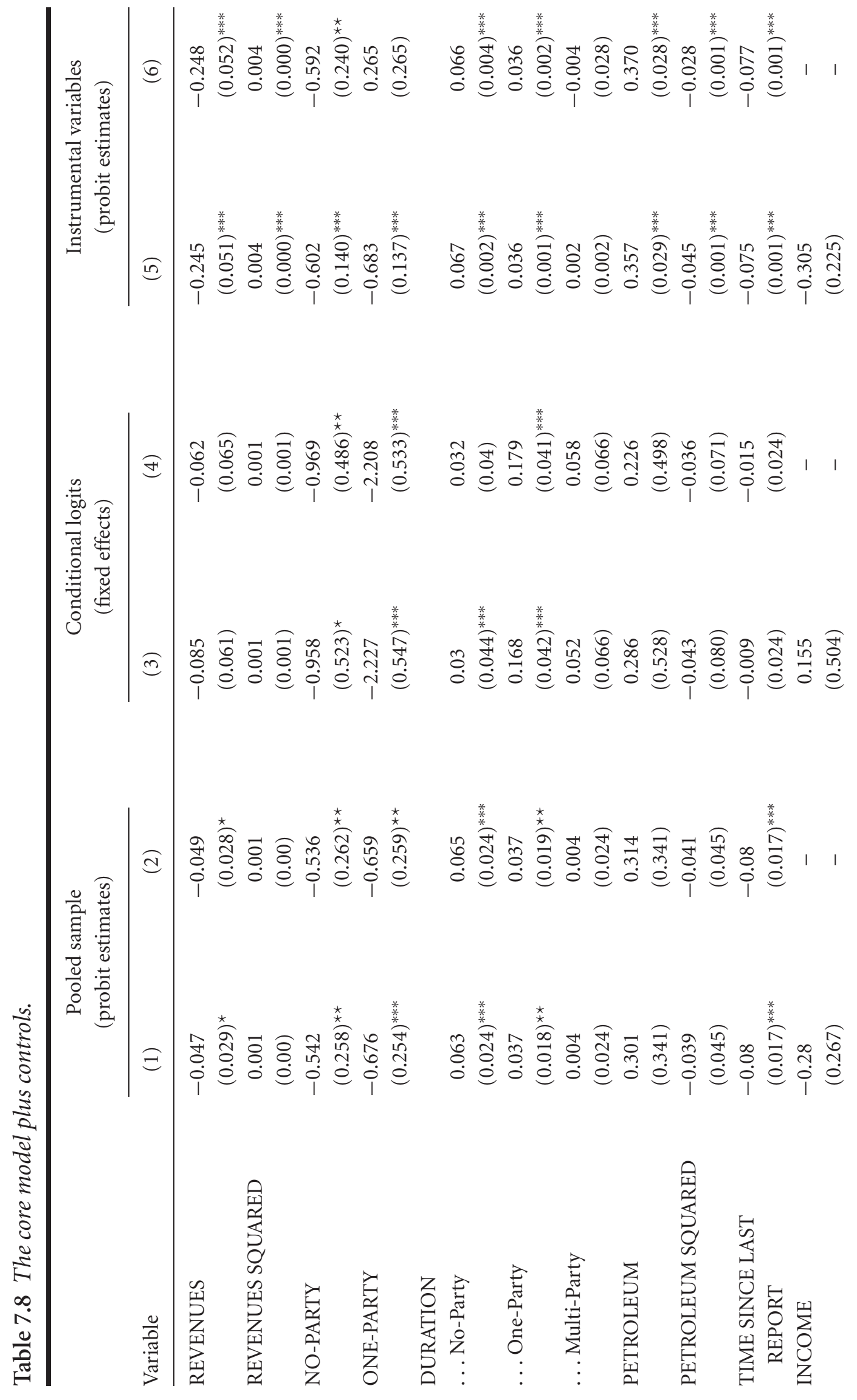




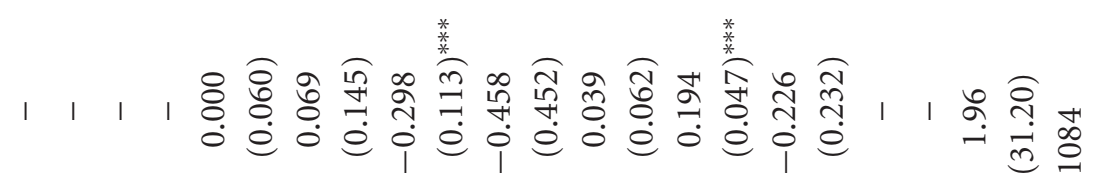

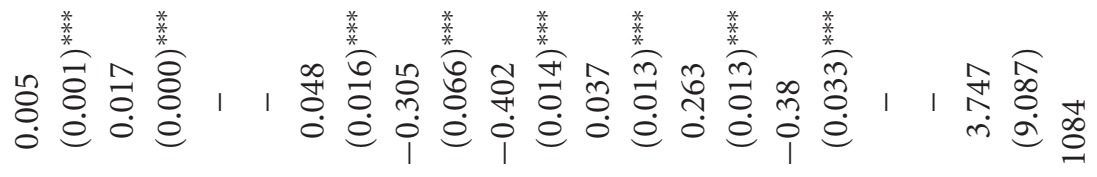

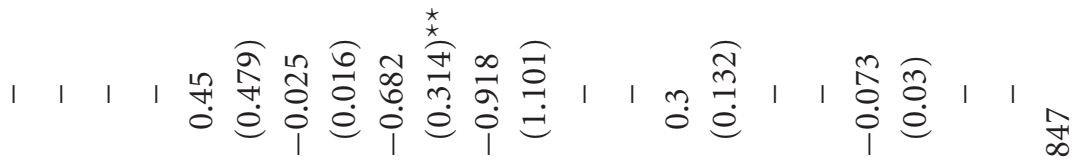

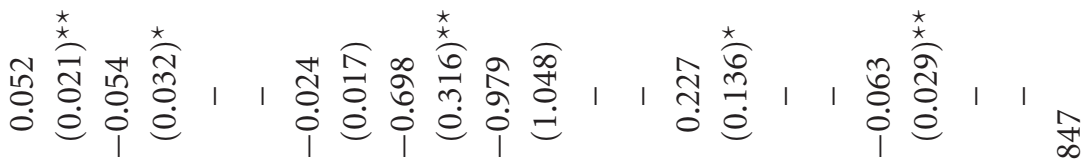

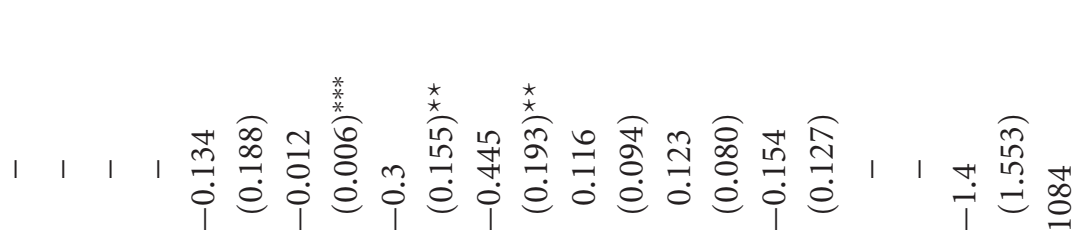

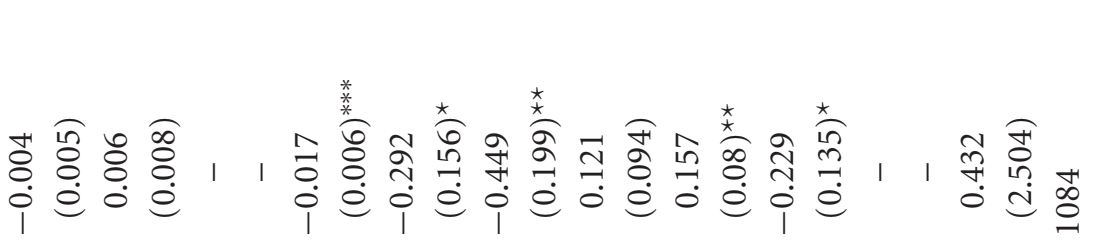

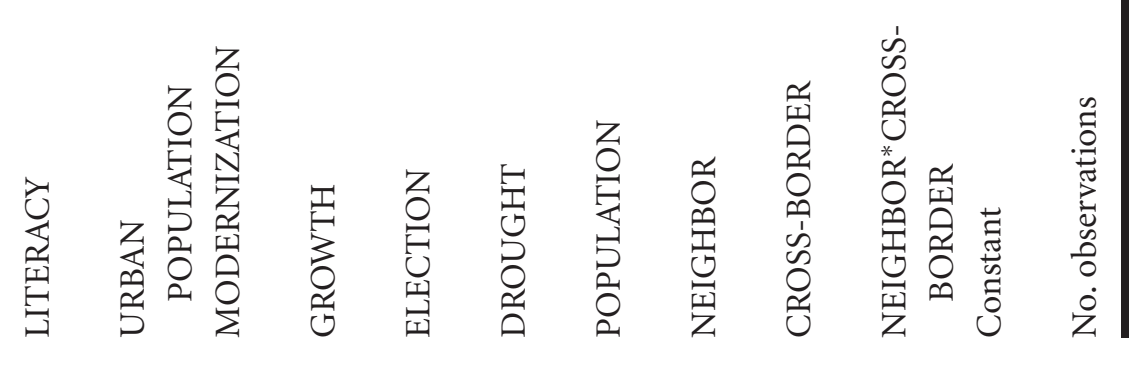

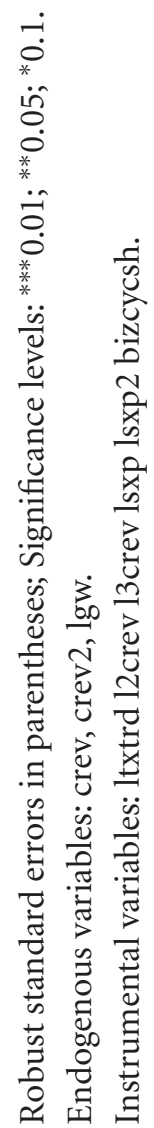


In this instance, the instrumental variables seek to correct for the endogeneity of GROWTH as well as REVENUES.

With one significant exception, the coefficients of the theoretical variables behave in the equations that include the control variables in the same manner, by and large, as they do in the equations of the core model. The exception is REVENUES, where the coefficient becomes much larger in the equations that incorporate instruments when the additional variables are entered into the equation. ${ }^{22}$

The coefficients linking the modernization variables to political disorder are insignificant in estimates drawn from the pooled sample. Those drawn from the fixed-effects equations suggest that increases in LITERACY and URBAN POPULATION can lead to increases in the likelihood of political disorder.

The estimates from the pooled equation suggest that GROWTH shocks and DROUGHT also affect the likelihood of disorder. Higher levels of GROWTH reduce the likelihood of domestic militarization; DROUGHT increases it. ${ }^{23}$ The estimates for GROWTH are not robust, however. When fixed effects or instrumental variables are introduced, the coefficient for GROWTH reverses in sign and it become insignificant in the fixedeffects models. Those for DROUGHT retain a positive sign, although they, too, lose significance when fixed effects are incorporated into the models.

More robust is the coefficient on the measure of political shocks, ELECTIONS. It is has been argued that elections are politically destabilizing. ${ }^{24}$ Our estimates offer little support for that argument: in each specification, the evidence indicates that there were fewer reports of militarized groups in the year before elections. One possibility is that political organizations alter the means by which they compete for power, changing from the use of violence to the search for votes. Another is that governments simply may not hold elections during periods of great insecurity and that the estimate is therefore biased.

As suggested by Herbst (2000) and Fearon and Laitin (2003), the coefficients on POPULATION suggest that larger countries may be more difficult to pacify. But differences in size do not bear a significant relationship to the likelihood of disorder in most specifications.

The coefficients on NEIGHBOR and CROSS-BORDER are of the expected sign and are significant in most equations.

22 Again, tests indicate that the instruments are not "weak."

23 The measure is the number of hectares of land per capita. Decreases in the measure therefore indicate increases in drought, and a negative sign on the coefficient suggests a positive relationship between drought and disorder.

24 Thus the title of Snyder's justly famous work (Snyder 2000). 
Turning to the estimates of the marginal effects of the variables, employing the coefficients generated when using instrumental variables, the results (not shown here) again confirm the importance of petroleum and the party system among the theoretical variables. The magnitude of their effect remains virtually unaltered when control variables are entered into the equations. Among the latter set of variables, it is income that emerges as the strongest correlate of disorder. The estimates suggest that moving 1 standard deviation above the mean in per capita income would reduce the likelihood of the formation of militias by 7 percentage points.

\subsection{Discussion}

The literature on political conflict in Africa stresses its economic origins. The results above suggest the need for greater nuance. While societies with lower incomes are more prone to political disorder, the evidence underscores the importance of political factors. While the literature emphasizes the role of GDP, this analysis emphasizes the role of public revenues: poorer states, it argues, are more likely to experience state failure. And while these accounts stress the role of economic factors, this points to the central importance of the party system.

Other literatures do emphasize political rather than economic sources of conflict. One variant focuses on the destabilizing role of democratization, stressing in particular the role of competitive elections (Zakaria 1997; Snyder 2000). The findings reported here call once again for a more nuanced interpretation. While competitive political systems are more likely to generate reports of private military groups than are no- or single-party systems, there is no evidence that elections themselves provoke the formation of private militias. The link between political reform and political disorder runs, the evidence suggests, not through electoral competition but rather through the fear of, and reaction to, the prospects of losing office.

The findings suggest that when states are starved or sated with revenues; when the incumbents in regimes hitherto immune to open political opposition must face organized political challengers; and when those in power have access to resource rents, then elites and citizens behave in ways that lead to state failure.

\section{In search of causal paths}

In closing, we return to the qualitative literature in search of the links between resource rents, political competition, and government revenues on the one hand, and state failure, on the other. 


\subsection{Petroleum production}

Regional conflict provides one link, be it between center and periphery or between those regions that lack and those that are blessed with an abundance of natural resources.

Among the issues that motivated the people of eastern Nigeria to take up arms against the central government in 1967 was their demand for control over petroleum deposits in the region. In key meetings between the leaders of the Eastern Region and the Central Government, Colonel Chukwuemeka Ojukukwi indicated that the Eastern Region would remain within Nigeria were the nation structured as a confederation - one in which the East would secure control over petroleum resources. The Central Government refused to accede to this proposal, however, largely (in the words of Khan 1994: 10) because of "the issue of oil revenue distribution."

With the breakdown of negotiations came the outbreak of the war. The Central Government's primary military objective (Dudley 1982: 113) was to seize the oil fields. The commander of the forces that secured that objective, Olesegun Obasanjo, still fights for control over Nigeria's petroleum deposits: now President of Nigeria, he has again moved troops to the oilproducing regions, seeking to repress rebels who, for their part, seek to check his attempts to seize the resources of their region on behalf of the central government (New York Times September 30, 2004: A11).

A similar narrative characterizes the Sudan. The central government and Southern Region had long struggled over issues as commonplace as political preferment and as volatile as race and religion. Shortly after independence, a mutiny of southern units of the armed forces led to the outbreak of war; years of fighting and subsequent compromises led to its termination. In 1978 came reports of the discovery of oil deposits in the northern reaches of the southern region. The national assembly then altered the regional boundaries, separating the oil fields from the south and locating them in the north, thereby placing them under de facto control of the central government. In combination with the political marginalization of Southern leaders and the imposition of Sharia law in the north, where many southerners lived, the loss of oil revenues led to the resumption of civil war (Mitchell 1993; Woodward 1995; de Waal 1997; Ali and Matthews 1999; Johnson 2003).

These narratives suggest that forces at the center mobilize their political and military might to capture the streams of income that emanate from Africa's natural resources, while those who dwell in the richly endowed region seek to capture that income for themselves. Both back up their claims with military force, thereby establishing a link between resource endowments and political conflict.

Qualitative accounts suggest an additional tie between resource wealth and state failure. They suggest that when the center succeeds in appropriating 
the wealth generated by natural endowments, the government no longer strives to provide services for its citizens. Recoded in terms of our analysis, the political contract between $G$ and the citizens appears then to break down: the specialist in violence no longer needs to exchange services, such as the protection of property rights, for the receipt of public revenues.

To illustrate, Amos Sawyer - once an opponent of the government of William Tolbert and later himself Liberia's President - points to the growth of government revenues from natural resources and its impact on the government's behavior: "iron ore royalties and other forms of business, especially multinational corporations, relieved the government from reliance on hut taxes," he writes, and "the government thus gained sources of income independent of the performance of its . . . administrative apparatus" (Sawyer 1992: 10). The result, in Sawyer's words, was the "emergence of autocracy": a presidency that ruled the country as a "personal domain" (1992: 10). Cilliers (2000) notes a similar pattern in Angola, where the revenue-sated political elites have retired to the presidential mansion, leaving it to the people themselves to provide their own health care, sanitation, housing, and security.

Returning to Nigeria, we can also turn to the comments of Billy Dudley (Dudley 1982): "the oil boom," he writes, "was a disaster" - one made worse by military rule. As Dudley states:

Under military rule, with no constituents to conciliate and no electorate to be accountable to - in however weak a sense one interprets the notion of accountabilitythe effect of the oil boom was to convert the military political decision makers into a new property-owning, rentier class working in close and direct collaboration with foreign business interests with the sole aim of expropriating the surpluses derived from oil for their own private benefit. (Dudley 1982: 116)

Qualitative materials thus suggest possible links between petroleum production and political order. One runs through the politics of income distribution, not between rich individuals and poor but rather between the center and the periphery or between regions endowed with natural resources and those that are not. ${ }^{25}$ A second runs through the incentives that shape the behavior of elites. Sated with resource wealth, those who govern no longer have an incentive to safeguard the welfare of their people in exchange for public revenues. Instead they abandon the strategies that, in equilibrium, support political order.

${ }^{25}$ While a new theme in this chapter, the impact of regional tensions is addressed in greater depth in chapter 6 by Azam and it is one to which we shall shortly return (see below). 


\subsection{Revenues}

Specialists in violence can transmute force into security; but they need to be paid to do so. If the flow of earnings from the provision of this service is worth less than the immediate benefits from predation (less the subsequent losses from state failure), then they will instead use force to engage in predation, rendering the citizenry less secure and more likely to pick up arms. This is one strand of the logic advanced in this chapter, and the estimates lend support to the argument.

The evidence from the literature suggests that the relationship runs along several different paths. One is through the non-payment of the military. Rather than paying their salaries, some governments instead accumulate arrears. This form of non-payment characterizes the francophone states, which are unable to monetize their debts. Decalo discusses the example of Benin (Decalo 1997: 11); O’Toole (1997) the case of the CAR; Yates (1996) the case of Gabon; and Mundt (1997), Huband (1998), and Hills (2000), the example of Côte d'Ivoire. In each instance, non-payment resulted in riots and looting by soldiers. Outside of the franc zone, non-payment takes a different form: the erosion of the real value of the soldiers' pay. Where central banks are able to lend to governments so that they can pay their debts, then governments can renege on those debts by increasing the supplyand thus lowering the value - of their currencies. Perhaps the best example comes from Zaire. ${ }^{26}$ When in 1993 Mobutu tried - once again - to pay his debts by issuing bank notes, his soldiers at last refused to accept them. They rebelled, refused payment, and turned to looting.

When left unpaid by their governments, specialists in violence seek to pay themselves. One way is through extortion. As stated by Kasozi (1994), in Uganda in the 1980s,

Any soldier who needed money ... would just pick an isolated ... part of the road, put logs or chains across it, and wait for unfortunate travelers. These twentieth century highwaymen would rob anyone of anything they fancied: cash, watches, cassette radios, clothes, and the like. (1994: 164)

General Kpama Baramoto, commander of the Civil Guard in Zaire, levied a toll on mineral and diamond production in Eastern Zaire, issued trading licenses, and, for turning a blind eye, took payments from smugglers (MacGaffey 1987: 60-2; Pech 2000). Or, as in Liberia, soldiers can turn into "sobels" - soldiers by day, rebels by night - thus enjoying the non-monetary perquisites of public employment, such as housing, and the financial rewards of rebellion: ransoms, loot, and plunder (Howe 2000: 57; see also Ellis 1999).

26 Among the numerous accounts, see Nzongola-Ntanlaja (2002). 
Soldiers possess another option, of course, and that is themselves to seize power. Illustrative are the memoirs of one James Waore Dianga, a junior officer who in August 1982 attempted to overthrow the government of Daniel Arap Moi, president of Kenya. Dianga and his colleagues witnessed a decline in the ability or inclination of the government to provide equipment that worked, uniforms that fitted, housing that was adequate, food that was palatable, or pay that would enable the soldiers to live in reasonable comfort. As stated by Dianga: "A soldier . . . signs a contract with the State ... The soldier, on his/her part, is under oath to defend the State ... The government enters into an agreement . . . to supply the soldier" (Dianga 2002: 48-9). The declining fortunes of the soldiers broke the letter of the contract, and the rising fortune of the President's cronies violated its spirit; in response, Dianga writes, the soldiers rebelled.

The attempted coup led by Flight Lieutenant Jerry Rawlings in Ghana in 1979 offers another example. Under-paid and without decent clothing or adequate shelter, the rank and file seethed in resentment as their officers themselves now in charge of the state - enriched themselves while abandoning to their fate those whom they commanded. Rawlings' denunciation of Ghana's elite and of their violation of the contract between the soldier and the state occupies a prominent place in Ghana's - indeed, in Africa's political heritage. ${ }^{27}$

Regionalism provides a second link. In Africa, as elsewhere, the desire for redistribution motivates politics. Regions that are relatively poor seek to extract revenues from those that are rich. Such efforts need not lead to conflict, however: with sufficient public revenues, elites from richer regions can retain the loyalty of those from the less prosperous regions by channeling benefits to them, thus forestalling armed challenges (Azam 1994).

Evidence comes from Côte d'Ivoire, where political order rested on a series of pacts negotiated between regional elites and the center (see Boone 2003 and Azam 1994). Southerners, and in particular the Akan, controlled the center. Prominent in the periphery were the Senoufo, who possessed a well-organized polity in the north. "The complaint of the north," Boone writes, was that "their region was impoverished and relegated to backward political status" (2003: 263). To counter mounting discontent, President Houphouët-Boigny launched “a massive infusion of resources" (2003: 263), starting projects that led to the opening of parastatal agencies, the construction of roads, and the founding of cotton and livestock industries in the region. Channeling an intensive flow of benefits in the area dominated by

27 Ironically, the statement emanates from the prosecution's depiction of the motives for the coup, rather then from the mouth of Rawlings himself. See the account in Shillington (1992) and Appiah (1996). 
the Senoufo, the government recruited members of the ruling clans into the agencies that managed these projects (Boone 2003: 267ff.).

This tactic is, of course, risky: should revenues fall, then the government may be unable to fulfill the key periphery's participation constraint. With the end of the coffee boom of the late 1970s, those in the center could no longer credibly pledge to target the north with projects (Rapley 1993). The north therefore began to organize against the central government. After the death of Houphouët-Boigny, the forces of the north gathered about Allasane Outtara: once Prime Minister, he now sought to become President. Led by Laurent Gbagbo, southern politicians rallied to check the rise of Outtara, portraying him as a non-national and therefore ineligible for high office. The courts agreed. Following a coup by soldiers whom the government had failed to pay, the rival politicians transformed their political organizations from political parties into armed militias and plunged Côte d'Ivoire into war. ${ }^{28}$

A second source of risk arises from the inconsistency of preferences and resultant inability to commit. In order to secure the demobilization of the periphery, the government may pledge to transfer resources. Once the periphery surrenders, however, the government may prefer to renege on its pledges. Knowing that, the periphery may therefore ignore the government's promises and refuse to demobilize. As stressed by Fearon (1998), Acemoglu and Robinson (2001), Azam and Mesnard (2003), and others, for co-optation to work, promises must be credible. ${ }^{29}$

In compiling data for the sample of forty-six African countries over 197095, I noted whether countries were marked by regional inequalities and whether the Chief Executive came from an economically privileged or a poorly endowed region. As seen in table 7.9, when the Chief Executive came from a less prosperous region, the likelihood of mass militarization declined. The marginal effects (not shown here) are large, suggesting that having a President from a non-prosperous region reduces the likelihood of militarization by 19 percentage points. The evidence thus suggests that insofar as regional differences matter, pledges of transfers tend to be incredible. Defusing the political tensions that arise between rich regions and poor appears to require that the elite from the poorer region secure the power to allocate the state's resources.

28 The split between the north and south was not the sole line of cleavage, it should be stressed. Particularly within the south, major animosities set the western regions against those of the east.

29 This arguments draws on the logic of the "security dilemma" that pervades multi-ethnic societies. See Posen (1993) and Fearon (1998). It also echoes the arguments advanced by Acemoglu and Robinson (2001) and Acemoglu and Robinson (2006) as they strive to identify when political order will give way to conflict or persist because of reform. It parallels most closely, however, the analysis of Azam and Mesnard (2003), who strive to explain the disintegration of Côte d'Ivoire. 
Table 7.9 President from non-prosperous region.

\begin{tabular}{|c|c|c|c|}
\hline Variable & $\begin{array}{l}\text { Pooled sample } \\
\text { (probit estimates) } \\
\text { (1) }\end{array}$ & $\begin{array}{l}\text { Conditional logits } \\
\text { (fixed effects) } \\
\text { (2) }\end{array}$ & $\begin{array}{l}\text { Instrumental variables } \\
\text { (probit estimates) } \\
\text { (3) }\end{array}$ \\
\hline REVENUES & $\begin{array}{c}-0.053 \\
(0.03)^{*}\end{array}$ & $\begin{array}{r}-0.051 \\
(0.07)\end{array}$ & $\begin{array}{l}-0.159 \\
(0.04)^{* * *}\end{array}$ \\
\hline REVENUES SQUARED & $\begin{array}{r}0.001 \\
(0.00)\end{array}$ & $\begin{array}{r}0.001 \\
(0.00)\end{array}$ & $\begin{array}{l}0.002 \\
(0.00)^{* * *}\end{array}$ \\
\hline $\begin{array}{l}\text { PRESIDENT FROM NON- } \\
\text { PROSPEROUS REGION }\end{array}$ & $\begin{array}{l}-0.362 \\
(0.17)^{* *}\end{array}$ & $\begin{array}{c}-0.727 \\
(0.35)^{*}\end{array}$ & $\begin{array}{l}-0.476 \\
(0.08)^{* * *}\end{array}$ \\
\hline NO-PARTY & $\begin{array}{l}-0.588 \\
(0.26)^{* *}\end{array}$ & $\begin{array}{r}-0.669 \\
(0.51)\end{array}$ & $\begin{array}{c}-0.545 \\
(0.29)^{*}\end{array}$ \\
\hline ONE-PARTY & $\begin{array}{c}-0.728 \\
(0.28)^{* * *}\end{array}$ & $\begin{array}{l}-1.812 \\
(0.58)^{* * *}\end{array}$ & $\begin{array}{c}-0.822 \\
(0.33)^{* *}\end{array}$ \\
\hline \multicolumn{4}{|l|}{ DURATION } \\
\hline ... No-Party & $\begin{array}{l}0.073 \\
(0.02)^{* * *}\end{array}$ & $\begin{array}{r}0.008 \\
(0.04)\end{array}$ & $\begin{array}{l}0.069 \\
(0.00)^{* * *}\end{array}$ \\
\hline ... One-Party & $\begin{array}{l}0.046 \\
(0.02)^{* *}\end{array}$ & $\begin{array}{l}0.141 \\
(0.05)^{* * *}\end{array}$ & $\begin{array}{l}0.056 \\
(0.00)^{* * *}\end{array}$ \\
\hline ... Multi-Party & $\begin{array}{r}0.001 \\
(0.02)\end{array}$ & $\begin{array}{r}0.012 \\
(0.07)\end{array}$ & $\begin{array}{r}-0.007 \\
(0.00)\end{array}$ \\
\hline PETROLEUM & $\begin{array}{r}0.227 \\
(0.33)\end{array}$ & $\begin{array}{r}1.404 \\
(1.18)\end{array}$ & $\begin{array}{c}0.244 \\
(0.03)^{* * *}\end{array}$ \\
\hline PETROLEUM SQUARED & $\begin{array}{r}-0.029 \\
(0.04)\end{array}$ & $\begin{array}{r}-0.161 \\
(0.14)\end{array}$ & $\begin{array}{l}-0.031 \\
(0.00)^{* * *}\end{array}$ \\
\hline MODERNIZATION & $\begin{array}{r}-0.128 \\
(0.18)\end{array}$ & $\begin{array}{r}1.122 \\
(0.80)\end{array}$ & $\begin{array}{r}-0.044 \\
(0.06)\end{array}$ \\
\hline GROWTH & $\begin{array}{l}-0.019 \\
(0.01)^{* * *}\end{array}$ & $\begin{array}{r}-0.025 \\
(0.02)\end{array}$ & $\begin{array}{r}0.127 \\
(0.16)\end{array}$ \\
\hline DROUGHT & $\begin{array}{l}-0.430 \\
(0.19)^{* *}\end{array}$ & $\begin{array}{r}-0.855 \\
(0.95)\end{array}$ & $\begin{array}{r}-0.540 \\
(0.48)\end{array}$ \\
\hline ELECTIONS & $\begin{array}{c}-0.305 \\
(0.16)^{*}\end{array}$ & $\begin{array}{c}-0.607 \\
(0.31)^{*}\end{array}$ & $\begin{array}{l}-0.283 \\
(0.10)^{* * *}\end{array}$ \\
\hline POPULATION & $\begin{array}{r}0.105 \\
(0.09)\end{array}$ & $\begin{array}{r}1.384 \\
(1.35)\end{array}$ & $\begin{array}{r}0.071 \\
(0.05)\end{array}$ \\
\hline NEIGHBORS & $\begin{array}{l}0.160 \\
(0.079)^{* *}\end{array}$ & $\begin{array}{l}- \\
-\end{array}$ & $\begin{array}{l}0.189 \\
(0.041)^{* * *}\end{array}$ \\
\hline CROSS-BORDER & $\begin{array}{l}-0.216 \\
(0.121)^{*}\end{array}$ & $\begin{array}{l}- \\
-\end{array}$ & $\begin{array}{c}-0.202 \\
(0.190)\end{array}$ \\
\hline $\begin{array}{l}\text { NEIGHBOR }^{\star} \text { CROSS }- \\
\text { BORDER }\end{array}$ & $\begin{array}{l}- \\
-\end{array}$ & $\begin{array}{c}-0.026 \\
(0.019)\end{array}$ & $\begin{array}{l}- \\
-\end{array}$ \\
\hline $\begin{array}{l}\text { TIME SINCE LAST } \\
\text { REPORT }\end{array}$ & $\begin{array}{l}-0.080 \\
(0.02)^{* * *}\end{array}$ & $\begin{array}{r}-0.005 \\
(0.03)\end{array}$ & $\begin{array}{c}-0.047 \\
(1.190)\end{array}$ \\
\hline Constant & $\begin{array}{c}-0.971 \\
(1.552)\end{array}$ & $\begin{array}{l}- \\
-\end{array}$ & $\begin{array}{c}0.851 \\
(20.701)\end{array}$ \\
\hline No. observations & 1048 & 813 & 1048 \\
\hline
\end{tabular}

Robust standard errors in parentheses; Significance levels: ${ }^{* * *} 0.01 ;{ }^{* *} 0.05 ;{ }^{*} 0.1$. 


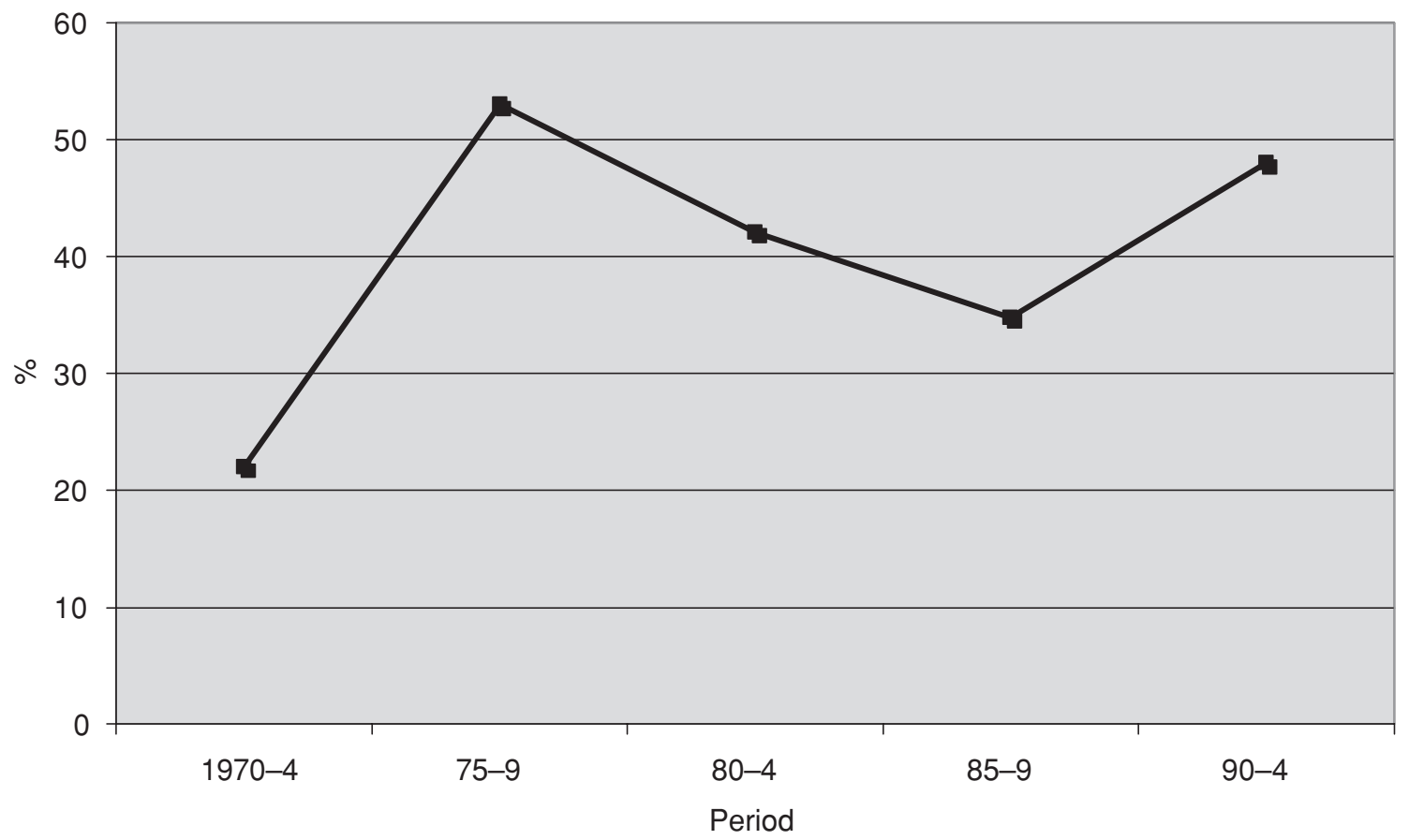

Figure 7.7 Rate of loss of office, by period, 1970-1994

\subsection{Political reform}

To probe the link between political reform and state failure, consider the level of risk faced by incumbent regimes. We have information concerning the departure from office of eighty-eight leaders over the period 1970-95. The number of incumbents rose from thirty-six at the beginning of the period to forty-six at the end. Figure 7.7 portrays the rate at which they lost office in each period; figure 7.8 the manner of their exit.

Viewed one way, the data suggest that African leaders faced less risk after the period of reform than they did in earlier periods. As seen in figure 7.7, in the period 1975-9, 53.5 percent of the leaders lost office as opposed to 48.8 percent in 1990-4. And as seen in figure 7.8, following the onset of political reform in 1989, the relative frequency of peaceful exits - resulting from resignations, electoral losses, or natural deaths - for the first time exceeded that of violent departures - resulting from coups, assassinations, or forceful expulsion from office. Data not presented here indicate that over 80 percent of the violent departures took place in no-party states - i.e. in states often ruled by the military. Over 60 percent of the peaceful exits took place in competitive party systems. These data give reason, then, to argue that political reform led to a less risky political environment.

Viewed another way, however, the data support an alternative vision. The risks to incumbents of coming to a violent end may have declined in the 


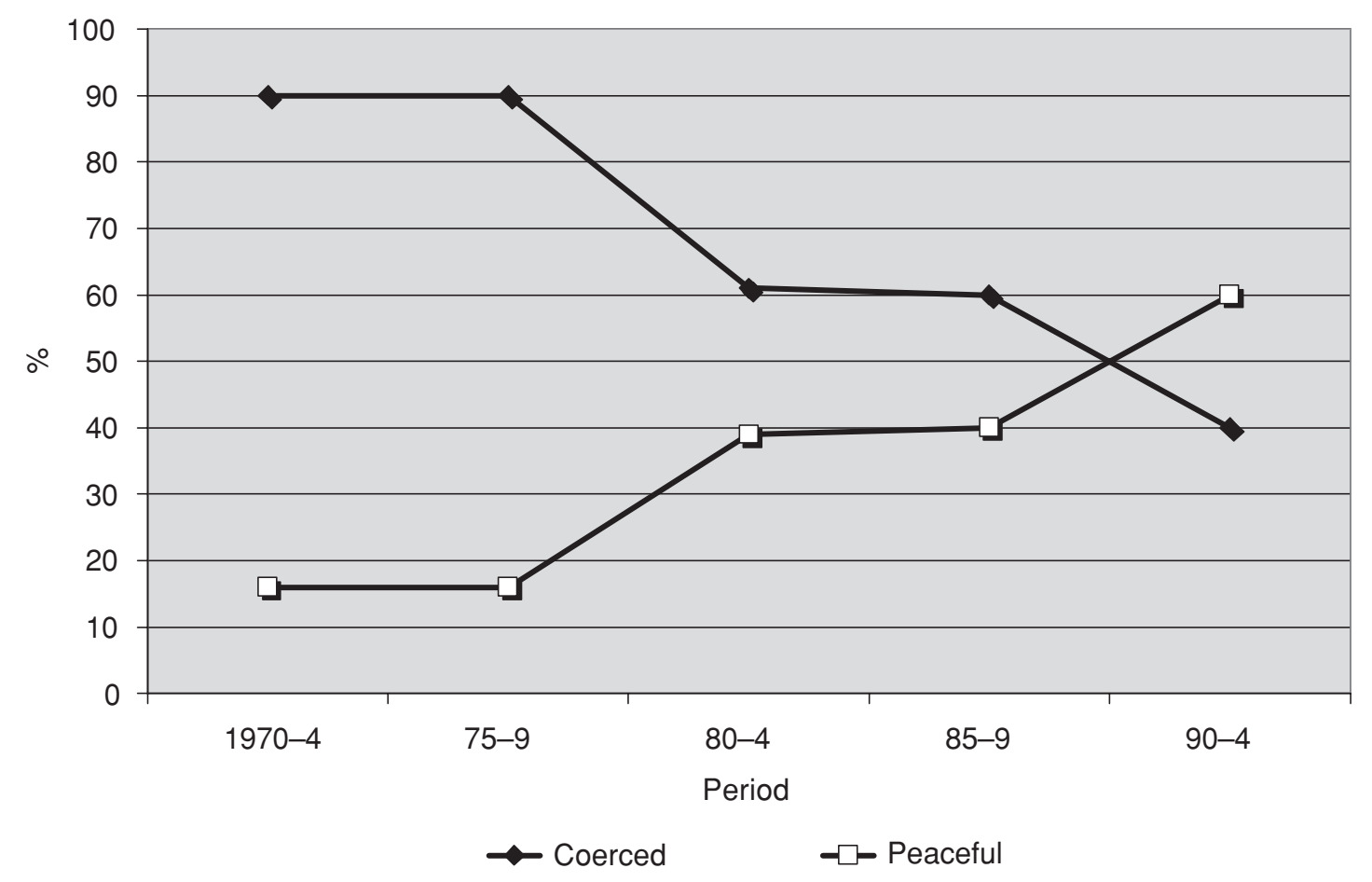

Figure 7.8 Forms of exit from office, by period, 1970-1994

sample period (figure 7.8). But the risk of loss of office rose (figure 7.7), returning to the level it had been in the late 1970s - the least stable period in post-independence Africa. Consider, moreover, the period just prior to reform: over the previous decade, the prospects of losing office had been declining and political leaders appeared to have gained an increasingly secure hold on power. As seen in figure 7.7, however, with 1989 came a rise in the level of political insecurity: the risk of loss of office rose sharply. Indicative of the leaders' own assessment, perhaps, is that 70 percent of the total voluntary exits from the post of Chief Executive took place in the period 1985-9440 percent in 1985-9 and 30 percent in 1990-4 - suggesting a downward revision in the leaders' assessment of their political prospects.

Some of Africa's leaders may have stepped down in the face of the threat posed by political reform; others fought back. Consider, for example, the case of Kenya in the 1990s. Daniel Arap Moi, the incumbent, came from the Rift Valley. The Valley contained forty-four of the 188 parliamentary constituencies. As the President could fill twelve other seats with nominees of his own, if he could consolidate his political base he would then be assured close to 30 percent of the parliamentary seats even before the outset of the campaign. But ethnic groups from other regions had migrated into the Rift Valley in search of land; and they tended to vote for the political parties that they had supported in their place of origin, which in key instances stood in 
opposition to the ruling party. The President and his backers, Kimenyi and Ndung'u (2005) claim, therefore launched a program of political intimidation. ${ }^{30}$ Organizing private militias, they invaded settler communities, beat and killed their residents, drove off their livestock, and burnt down shops, schools, and homes. Fearing the loss of power, the incumbent turned predatory and used force to violate rather than to safeguard the security of citizens. As Kimenyi and Ndung'u (2005) conclude, "the main motivation behind the violence was to influence voting in favor of the [ruling party]" (2005: 326).

Consider, too, the case of Sierra Leone. Most accounts of political conflict in Sierra Leone begin with the 1991 invasion of the RUF. But other accounts, especially those written by scholars from Sierra Leone, start earlier, focusing on the conduct of the APC, the ruling party.

In the 1970s, the APC faced challenges from its traditional rival, the SLPP, and from dissidents disillusioned by the decline in Sierra Leone's economy under the APC. ${ }^{31}$ The APC responded violently to these threats to its power. In a manner that foreshadowed later events in Rwanda and Zimbabwe, the governing party mobilized the party's youth league and the government's police to break up the rallies of the opposition parties; to beat up its sympathizers; and to intimidate those in the media that might sympathize with their cause. Fearing the loss of power, the ruling party turned violent. As stated by a prominent member of the opposition, the APC

had no support in the East. So how were they going to win? They knew they would win in the North and Western areas, but not in the East. Parliament would then be balanced between the two parties. They wanted to win, so there was violence. ${ }^{32}$ (Quoted in Hayward and Kandeh 1987: 50)

When civil war later broke out in Sierra Leone, a major goal of the combatants was to rid themselves of a political elite that was willing to attack its own people in order to retain political office.

It was when the political elite faced the prospect of losing office that governments turned predatory. Table 7.10 notes the dates when "national conferences" were convened. At these conferences, citizens joined politicians in debating the performance and structure of their governments. Several conferences assumed sovereign powers; virtually all reintroduced multiparty systems. In the face of such challenges, governments began to attack their citizens. Consider figure 7.9, for example, which presents the mean Freedom House Ratings for all countries which were independent by 1988. On the surface, it portrays Africa's widely celebrated move to democracy.

30 For confirmation of this account, see also Kenya (1992); Human Rights Watch/Africa (1993); Hempstone (1997).

31 Which started in 1968.

32 See also Barrows (1976); Abdullah (2004); Kandeh (2004). 
Table 7.10 National conferences.

\begin{tabular}{|c|c|c|c|c|c|c|}
\hline \multirow[b]{2}{*}{ Country } & \multirow[b]{2}{*}{ Date } & \multirow[b]{2}{*}{ Duration } & \multicolumn{2}{|c|}{ Election } & \multicolumn{2}{|c|}{ Outcome: Incumbent } \\
\hline & & & Month & $\mathrm{F} \& \mathrm{~F}$ ? & Ousted & Retained \\
\hline \multirow[t]{2}{*}{ Benin } & \multirow[t]{2}{*}{ Feb. 1990} & \multirow[t]{2}{*}{1 week } & Feb. 1991 & yes & $\sqrt{ }$ & \\
\hline & & & Mar. 1996 & yes & $\sqrt{ }$ & \\
\hline Congo & Feb. 1991 & 3 months & Aug. 1992 & yes & $\sqrt{ }$ & \\
\hline Gabon & Mar. 1990 & 3 weeks & Dec. 1993 & no & & $\sqrt{ }$ \\
\hline Mali & Jul. 1991 & 2 weeks & Apr. 1992 & yes & $\sqrt{ }$ & \\
\hline Niger & Jul. 1991 & 6 weeks & Feb. 1993 & yes & $\sqrt{ }$ & \\
\hline Burkina Faso & Aug. 1991 & 2 months & Dec. 1991 & no & & $\sqrt{ }$ \\
\hline Ghana & Aug. 1991 & 7 months & Dec. 1992 & yes & & $\sqrt{ }$ \\
\hline Togo & Aug. 1991 & 1 month & Aug. 1993 & no & & $\sqrt{ }$ \\
\hline Zaire & Aug. 1991 & 1 year & - & - & & \\
\hline CAR & Oct. 1991 & 2 months & Aug. 1992 & yes & $\sqrt{ }$ & \\
\hline Chad & Jan. 1993 & 3 months & Jun. 1996 & no & & $\sqrt{ }$ \\
\hline
\end{tabular}

Note: F\&F refers to whether international observers ruled the election "free and fair."

Source: Zartman (1997): 41.

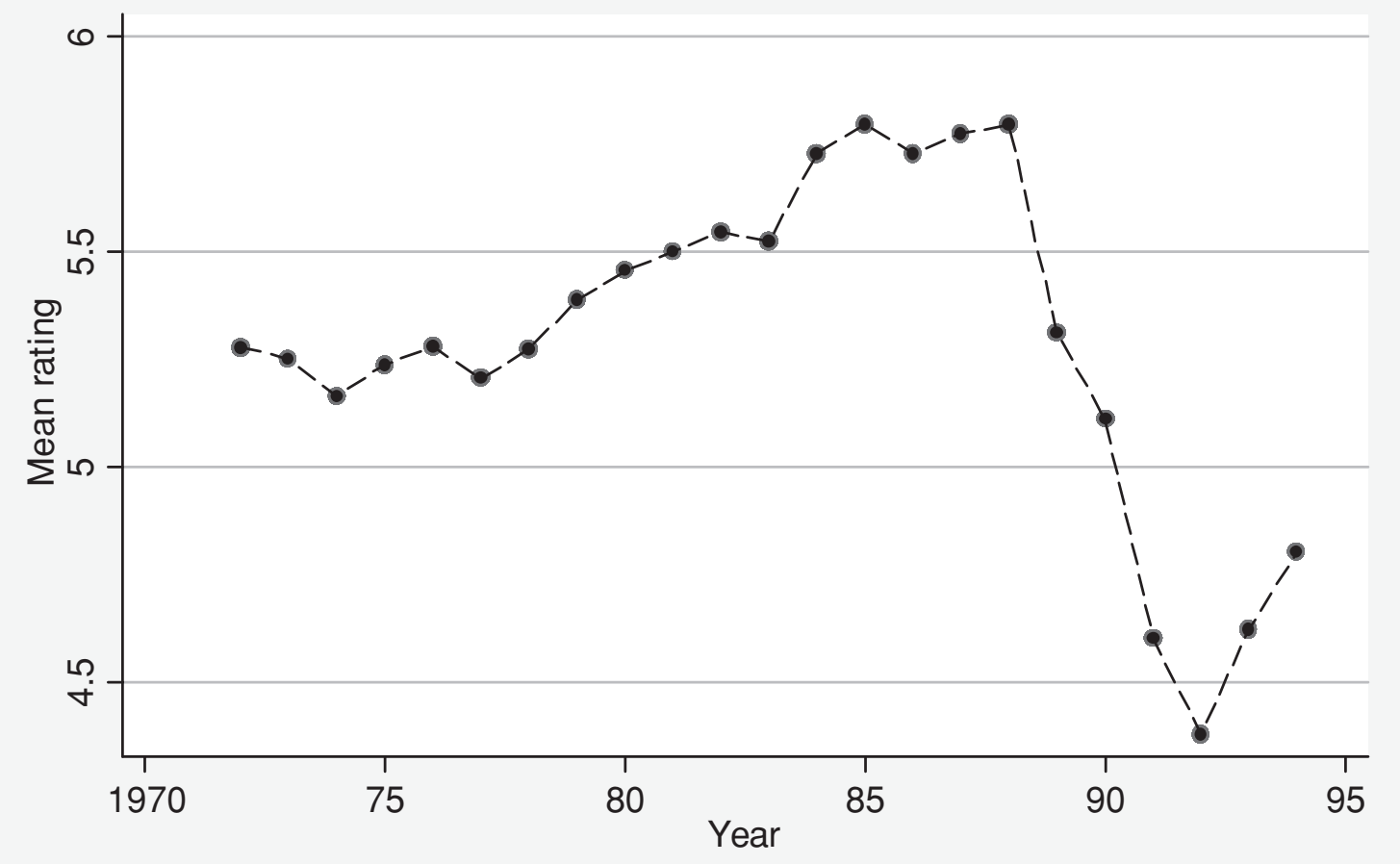

Figure 7.9 Civil liberties, by year, Freedom House Ratings, 1970-1995 
But then take a deeper look and remove from the sample "sharp improvers," countries whose scores improved by more than 2 points between 1988 and 1994. These were São Tomé and Principe $(-5)$, Benin, Cape Verde, and Malawi (-4), and Guinea-Bissau and South Africa (-3). Setting these aside, we can see higher (and therefore worse) average scores for the remaining forty countries, suggesting their relative failure to reform and, more relevantly, an upward spike in their scores in the early 1990s. Lying below such figures are such incidents as the Saba Saba killings in Kenya, when government forces shot down twenty-eight people at a rally called by an opposition party; the drowning of protestors in the Bé Lagoon of Lomé in 1991 and the slaughter of protestors by soldiers in 1993, which resulted in the fleeing of Togo by thousands of refugees (Heilbrunn 1993); the 1993 massacres of the ruling armed forces in Burundi; and genocides in Kasai, orchestrated by Mobutu to disrupt the political opposition (Huband 2001; see also Monga 1996 and Hempstone 1997). Just as political reform became more likely, so, too, did many governments become more willing to violate the rights of their citizens.

Recall the findings above: most elections do not result in the taking up of arms; they appear to induce demobilization. What appears to trigger the militarization of political life is the prospect of the loss of power. When incumbents sense that they will lose in open competition for office, they then mobilize the power of the state to vanquish their opponents. As phrased by Keen, there is an "elite backlash" (Keen 2000: 24). And civic society, feeling insecure, becomes more likely to organize in defense of their lives and property.

\section{Conclusion}

This chapter has probed the roots of political disorder and state collapse. Analyzing the conditions under which governments would use force to protect rather than to predate and people would delegate the use of coercion to those who govern, this chapter has addressed the causes of state breakdown in contemporary Africa. Africa shows that the Weberian state is not a given. It results when these choices form an equilibrium. The poverty of the state, the prospects of wealth from predation, and the prospect of losing office form the conditions under which this equilibrium will collapse and governments trigger the rise of political disorder.

\section{References}

Abdullah, Ibrahim, ed. (2004), Between Democracy and Terror. Dakar: CODESRIA Acemoglu, Daron and James A. Robinson (2001), "A Theory of Political Transitions," American Economic Review 91: 938-63 
(2006), Economic Origins of Dictatorship and Democracy. Cambridge: Cambridge University Press

Adibe, Clement A. (2001), "Foreign Policy Decisionmaking in Anglophone West Africa," in G. M. Khadiagala and T. Lyons, eds., African Foreign Policies. Boulder, CO: Lynne Rienner

Alemayehu Geda (2007), “The Political Economy of Growth in Ethiopia,” chapter 4 in Benno J. Ndulu, Stephen A. O’Connell, Jean-Paul Azam, Robert H. Bates, Augustin Kwasi Fosu, Jan Willem Gunning, and Dominique Njinkeu, eds., The Political Economy of Economic Growth in Africa, 1960-2000, vol. 2. Cambridge: Cambridge University Press

Ali, Ali Abdel Gadir and Ibrahim A. Elbadawi (2007), "Explaining Sudan's Economic Growth Performance,” chapter 7 in Benno J. Ndulu, Stephen A. O’Connell, Jean-Paul Azam, Robert H. Bates, Augustin Kwasi Fosu, Jan Willem Gunning, and Dominique Njinkeu, eds., The Political Economy of Economic Growth in Africa, 1960-2000, vol. 2. Cambridge: Cambridge University Press

Ali, Taisier M. and Robert O. Matthews (1999), "Civil Wars and Failed Peace Efforts in Sudan," in T. M. Ali and R. O. Matthews, eds., Civil Wars in Africa. Montreal: McGill-Queen's University Press

Appiah, Joe (1996), The Autobiography of an African Patriot. Accra: Asempa Publishers

Arellano, M. and S. Bond (1991), "Some Tests of Specification for Panel Data," Review of Economic Studies 58: 277-97

Azam, Jean-Paul (1994), "How to Pay for Peace? A Theoretical Framework with Reference to African Countries," Public Choice 83: 173-84

Azam, Jean-Paul and Nadjiounoum Djimtoïngar (2007), "Cotton, War, and Growth in Chad, 1960-2000," chapter 3 in Benno J. Ndulu, Stephen A. O'Connell, JeanPaul Azam, Robert H. Bates, Augustin Kwasi Fosu, Jan Willem Gunning, and Dominique Njinkeu, eds., The Political Economy of Economic Growth in Africa, 1960-2000, vol. 2. Cambridge: Cambridge University Press

Azam, Jean-Paul and Alice Mesnard (2003), "Civil War and the Social Contract," Public Choice 115: 455-75

Banks, Arthur (1999), "Cross-national Times Series Data Archive," Center for Social Analysis, Binghamton, NY. State University of New York at Binghamton

Barrows, Walter (1976), Grassroots Politics in an African State. New York: Africana Publishing

Bates, Robert H. (1981), Markets and States in Tropical Africa. Berkeley, CA and Los Angeles, CA: University of California Press

Bates, Robert H., Avner Greif, and Smita Singh (2002), "Organizing Violence," Journal of Conflict Resolution 46: 599-628

Block, Steven A. (2002), "Political Business Cycles, Democratization, and Economic Reform: The Case of Africa," Journal of Development Economics 67: 205-28

Boone, Catherine (2003), Political Topographies of the African State: Territorial Authorities and Institutional Choice. Cambridge and New York: Cambridge University Press

Bratton, Michael and Nicolas van de Walle (1997), Democratic Experiments in Africa. Cambridge: Cambridge University Press 
Chaudry, Kiren Aziz (1997), The Price of Wealth. Ithaca, NY: Cornell University Press

Cilliers, Jakkie (2000), "Resource Wars - A New Type of Insurgency," in Christian Dietrich and Jakkie Cilliers, eds., Angola's War Economy: The Role of Oil and Diamonds. Pretoria: Institute for Security Studies

Collier, Paul, V. L. Elliott, Havard Hegre, Anke Hoeffler, Marta Reynal-Querol, and Nicolas Sambanis (2003), Breaking the Conflict Trap. Washington DC: Oxford University Press for the World Bank

Collier, Paul and Anke Hoeffler (2002), "Greed and Grievance in Civil Wars," CSAE, Oxford

Collier, Paul, Anke Hoeffler, and Catherine Pattillo (1999), "Flight Capital as a Portfolio Choice," Washington DC: International Monetary Fund

(2002), "Africa's Exodus: Capital Flight and the Brain Drain as Portfolio Decisions," Washington, DC: The World Bank

Davies, Victor (2007), "Sierra Leone's Economic Growth Performance, 1961-2000," chapter 19 in Benno J. Ndulu, Stephen A. O’Connell, Jean-Paul Azam, Robert H. Bates, Augustin Kwasi Fosu, Jan Willem Gunning, and Dominique Njinkeu, eds., The Political Economy of Economic Growth in Africa, 1960-2000, vol. 2. Cambridge: Cambridge University Press

de Sousa, Clara Ana and Jose Sulemane (2007), "Mozambique's Growth Performance, 1960-1996," chapter 24 in Benno J. Ndulu, Stephen A. O’Connell, Jean-Paul Azam, Robert H. Bates, Augustin Kwasi Fosu, Jan Willem Gunning, and Dominique Njinkeu, eds., The Political Economy of Economic Growth in Africa, 1960-2000, vol. 2. Cambridge: Cambridge University Press

de Waal, Alex (1991), Evil Days. New York: Human Rights Watch

(1997), Famine Crimes: Politics and the Disaster Relief Industry in Africa. Oxford: James Currey with African Rights and the International African Institute

Decalo, Samuel (1997), "Benin: The First of the New Democracies," in J. F. Clark and D. E. Gardinier, eds., Political Reform in Francophone Africa. Boulder, CO: Westview Press

Dianga, James Waore (2002), Kenya, 1982: The Attempted Coup. London: Penn Press Dossou, Antonin S., Jean-Yves Sinzogan, with Sylviane Mensah (2007), "Economic Growth Benin: Lost Opportunties," chapter 22 in Benno J. Ndulu, Stephen A. O'Connell, Jean-Paul Azam, Robert H. Bates, Augustin Kwasi Fosu, Jan Willem Gunning, and Dominique Njinkeu, eds., The Political Economy of Economic Growth in Africa, 1960-2000, vol. 2. Cambridge: Cambridge University Press

Doumbouya, Sékou F. and Fodé Camara (2007), "Explaining Economic Growth in Africa: The Case of Guinea," chapter 17 in Benno J. Ndulu, Stephen A. O'Connell, Jean-Paul Azam, Robert H. Bates, Augustin Kwasi Fosu, Jan Willem Gunning, and Dominique Njinkeu, eds., The Political Economy of Economic Growth in Africa, 1960-2000, vol. 2. Cambridge: Cambridge University Press

Dudley, Billy (1982), An Introduction to Nigerian Government and Politics. Bloomington, IN: Indiana University Press

Ellis, Stephen (1999), The Making of Anarchy. New York: New York University Press Englebert, Pierre (2000), State Legitimacy and Development in Africa. Boulder, CO: Lynne Rienner 
Englebert, Pierre, Stacy Tarango, and Matthew Carter (2002), "Dismemberment and Suffocation: A Contribution to the Debate on African Boundaries," Comparative Political Studies 35: 1093-1118

Fearon, James D. (1995), "Rationalist Explanations for War," International Organizations 49: 379-414

(1998), "Commitment Problems and the Spread of Ethnic Conflict," in D. A. Lake and D. Rothchild, The International Spread of Ethnic Conflict. Princeton, NJ: Princeton University Press

(2003), "Ethnic Structure and Cultural Diversity by Country," Journal of Economic Growth 8: 195-222

Fearon, James and Laitin, David (2003), "Ethnicity, Insurgency and Civil War," American Political Science Review 97: 75-90

Fosu, Augustin (1992), "Political Instability and Economic Growth: Evidence from Sub-Saharan Africa," Economic Development and Cultural Change 40: 823-41

Fukuyama, Francis (2004), State-building: Governance and World Order in the 21st Century. Ithaca, NY: Cornell University Press

Gleditsch, Nils Petter, Peter Wallensteen, Mikael Eriksson, Margareta Sollenberg, and Havard Strand (2002), "Armed Conflict 1946-2001: A New Data Set," Journal of Peace Research 39: 615-37

Grossman, Herschel I. and D. Kim (1995), “The Economics of Revolutions,” Department of Economics, Brown University, Providence, RI

Gyimah-Brempong, Kwabena and Marva E. Corley (2005), "Civil Wars and Economic Growth in South Africa," Journal of African Economies 14: 270-311

Gyimah-Brempong, Kwabena and Thomas L. Traynor (1999), "Political Instability, Investment, and Economic Growth in Sub-Saharan Africa," Journal of African Economies 8: 52-86

Hayward, Fred M. and Jimmy D. Kandeh (1987), "Perspectives on Twenty-five Years of Elections in Sierra Leone," in F. M. Hayward, ed., Elections in Independent Africa. Boulder, CO: Westview Press

Heilbrunn, John (1993), "Social Origins of National Conferences in Benin and Togo," Journal of Modern African Studies 31: 277-99

Hempstone, Smith (1997), Rogue Ambassador: An African Memoir. Sewanee, TN: University of the South Press

Herbst, Jeffrey (2000), States and Power in Africa. Princeton, NJ: Princeton University Press

Hills, Alice (2000), Policing Africa. Boulder, CO: Lynne Rienner

Hirsch, John (2001), Sierra Leone: Diamonds and the Struggle for Democracy. Boulder, CO: Lynne Rienner

Honaker, James (2000), "Issues in Multiple Imputation of Data of the African Research Program,” Department of Government, Harvard University, Cambridge, MA

Howe, Herbert M. (2000), Ambiguous Order: Military Forces in African States. Boulder, CO: Lynne Rienner

Huband, Mark (1998), The Liberian Civil War. London: Frank Cass

(2001), The Skull beneath the Skin: Africa After the Cold War. Boulder, CO: Westview Press 
Human Rights Watch (1999), Angola Unravels. New York: Human Rights Watch Human Rights Watch/Africa (1993), Divide and Rule: State Sponsored Ethnic Violence in Kenya. New York: Human Rights Watch

Hyden, Goran (1981), No Shortcuts to Progress. Berkeley, CA and Los Angeles, CA: University of California Press

Jackson, Robert H. and Carl G. Rosberg (1982), Personal Rule in Black Africa. Berkeley, CA and Los Angeles, CA: University of California Press

Johnson, Douglas H. (2003), The Root Causes of Sudan's Civil War. Bloomington, IN: Indiana University Press

Judson, R. and A. Owen (1999), "Estimating Dynamic Panel Data Models: A Guide for Macroeconomists," Economics Letters 65: 9-15

Kandeh, Jimmy D. (2004), "In Search of Legitimacy: The 1966 Elections," in I. Abdullah, ed., Between Democracy and Terror. Dakar: CODESRIA

Kasekende, Louis A. and Michael Atingi-Ego (2007), "Restarting and Sustaining Growth in a Post-conflict Economy: The Case of Uganda," chapter 8 in Benno J. Ndulu, Stephen A. O'Connell, Jean-Paul Azam, Robert H. Bates, Augustin Kwasi Fosu, Jan Willem Gunning, and Dominique Njinkeu, eds., The Political Economy of Economic Growth in Africa, 1960-2000, vol. 2. Cambridge: Cambridge University Press

Kasozi, A. B. K. (1994), The Social Origins of Violence in Uganda, 1964-1985. Montreal: McGill-Queen's University Press

Keen, David (2000), "Incentives and Disincentives for Violence," in M. Berdal and D. Malone, eds., Greed and Grievance: Economic Agendas in Civil Wars. Boulder, CO: Lynne Rienner

Kenya, Republic of (1992), "Report of the Parliamentary Select Committee to Investigate Ethnic Clashes in Western and Other Parts of Kenya," Nairobi: Government Printer

Khan, Sarah Ahmed (1994), Nigeria: The Political Economy of Oil. Oxford: Oxford University Press for the Oxford Institute for Energy Studies

Kimenyi, Mwangi S. and Njuguna Ndung'u (2005), "Sporadic Ethnic Violence: Why Has Kenya not Experienced a Full Blown Civil War?," in Paul Collier and Nicholas Sambanis, eds., Understanding Civil War: Evidence and Analysis (Volume 1: Africa). Washington, DC: The World Bank

Kirk-Greene, A. H. M. (1971), Crisis and Conflict in Nigeria. London: Oxford University Press

MacGaffey, Janet (1987), Entrepreneurs and Parasites: The Struggle for Indigenous Capitalism in Zaïre. Cambridge: Cambridge University Press

(1991), The Real Economy of Zaire. Philadelphia, PA: University of Pennsylvania Press

MacGaffey, Janet and Rémy Bazenguissa-Ganga (2000), Congo-Paris: Transnational Traders on the Margins of the Law. Oxford: James Currey

Miguel, Edward, Shanker Satyanath, and Ernest Sergenti (2004), "Economic Shocks and Civil Conflict," Journal of Political Economy 112(4): 725-53

Mitchell, Christopher (1993), "The Process and Stages of Mediation: Two Sudanese Cases," in D. Smock, ed., Making War and Waging Peace: Foreign Intervention in Africa. Washington, DC: United States Institute of Peace Press

Monga, Celestin (1996), The Anthropology of Anger. Boulder, CO: Lynne Rienner 
Morrison, Donald, Robert Mitchell, John Paden, and Hugh Stevenson (1989), Black Africa: A Comparative Handbook. New York: Paragon House

Moselle, Boaz and Ben Polak (2001), "A Model of a Predatory State," Journal of Law Economics and Organization 17(1): 1-33

Mundt, Robert J. (1997), "Côte d'Ivoire: Continuity and Change in a Semidemocracy," in J. F. Clark and D. E. Gardinier, eds., Political Reform in Francophone West Africa. Boulder, CO: Westview Press

Murdoch, J. and Todd Sandler (2002), "Economic Growth, Civil Wars, and Spatial Spillovers," Journal of Conflict Resolution 46: 91-110

Muthoo, Abhinay (2000), "On the Foundations of Property Rights, Part 1: A Model of the State-of-nature with Two Players," TJJ

Mwega, Francis M. and Njuguna S. Ndung'u (2007), "Explaining African Growth Performance: The Case of Kenya," chapter 10 in Benno J. Ndulu, Stephen A. O'Connell, Jean-Paul Azam, Robert H. Bates, Augustin Kwasi Fosu, Jan Willem Gunning, and Dominique Njinkeu, eds., The Political Economy of Economic Growth in Africa, 1960-2000, vol. 2. Cambridge: Cambridge University Press

Nkurunziza, Janvier and Floribert Ngaruko (2007), "Why Has Burundi Grown so Slowly? The Political Economy of Redistribution," chapter 2 in Benno J. Ndulu, Stephen A. O'Connell, Jean-Paul Azam, Robert H. Bates, Augustin Kwasi Fosu, Jan Willem Gunning, and Dominique Njinkeu, eds., The Political Economy of Economic Growth in Africa, 1960-2000, vol. 2. Cambridge: Cambridge University Press

Nzongola-Ntanlaja, Georges (2002), The Congo from Leopold to Kabila. London: Zed Books

O’Toole, Thomas (1997), “The Central African Republic: Political Reform and Social Malaise," in J. F. Clark and D. E. Gardinier, eds., Political Reform in Francophone Africa. Boulder, CO: Westview Press

Pech, Khareen (2000), "The Hand of War: Mercenaries in the Former Zaire 199697," in A.-F. Musah and J. K. Fayemi, eds., Mercenaries: An African Security Dilemma. London: Pluto Press

Posen, Barry (1993), "The Security Dilemma and Ethnic Conflict," Survival 35: 27-47

Rapley, John (1993), Ivoirien Capitalism: African Entrepreneurs in Côte d'Ivoire. Boulder, CO: Lynne Rienner

Reno, William (1998), Warlord Politics and African States. Boulder, CO: Lynne Rienner

(2000), "The Real (War) Economy of Angola," in Christian Dietrich and Jakkie Cilliers, eds., Angola's War Economy. Pretoria: Institute for Security Studies

Ross, Michael (2003), "The Natural Resource Curse: How Wealth Can Make You Poor," in I. Bannon and Paul Collier, eds., Natural Resources and Violent Conflict. Washington, DC: The World Bank

Rubin, D. B. (1996), “Multiple Imputation after 18+ years (with Discussion), J Journal of the American Statistical Association 91: 473-89

Sambanis, Nicholas (2001), "A Review of Recent Advances and Future Directions in the Quantitative Literature on Civil War." New Haven, CT: Yale University 
Sawyer, Amos (1992), The Emergence of Autocracy in Liberia. San Francisco, CA: ICS Press

Schafer, Joseph L. (1997), "Imputation of Missing Covariates in the Multivariate Linear Mixed Model.” Department of Statistics, University Park, PA: The Pennsylvania State University

Sen, Amartya (1984), Poverty and Famines. Oxford: Clarendon Press

Shillington, Kevin (1992), Ghana and the Rawlings Factor. London: Macmillan

Skaperdas, Stergios (1992), "Cooperation, Conflict, and Power in the Absence of Property Rights," American Economic Review 82: 720-38

(1996), "Gangs and the State of Nature," in P. Newman, The New Palgrave Dictionary of Economics and the Law. London: Palgrave

Snyder, Jack (2000), From Voting to Violence. New York: W.W. Norton

Strand, Havard, Lars Wilhelmsen, and Nils Petter Gleditsch (2002), "Armed Conflict Data Codebook," Peace Research Institute, Oslo

Suberu, Rotimi T. (2001), Federalism and Ethnic Conflict in Nigeria. Washington, DC: United States Institute of Peace Press

Tilly, Charles (1975), "Reflections on the History of State Making," in Charles Tilly, ed., The Formation of National States in Western Europe. Princeton, NJ: Princeton University Press

Usher, Dan (1989), "The Dynastic Cycle and the Stationary State," American Economic Review 79: 1031-44

Weber, Max (1921), "Politik als Beruf," Gesammelte Politische Schriften. Munich: Duncker \& Humblot

Woodward, Peter (1995), "Sudan," in O. Furley, Conflict in Africa. London: I.B. Tauris

World Bank (1991), Governance and Development. Washington, DC: The World Bank

(1994), Adjustment in Africa: Reform, Results, and the Road Ahead. Washington, DC: The World Bank

Yates, Douglas (1996), The Rentier State in Africa: Oil Rent Dependency and Neocolonialism in the Republic of Gabon. Trenton, NJ: Africa World Press

Zakaria, Fareed (1997), “The Rise of Illiberal Democracy," Foreign Affairs 76: 22-43

Zartman, I. W. (1997), Governance as Conflict Management. Washington, DC: Brookings Institution Press

Zinn, Annalisa (2005), "Theory versus Reality: Civil War Onset and Avoidance in Nigeria Since 1960," in Paul Collier and Nicholas Sambanis, eds., Understanding Civil War: Evidence and Analysis (Volume 1: Africa). Washington, DC: The World Bank: 89-122 